Article

\title{
Encapsulation and Ultrasound-Triggered Release of G-Quadruplex DNA in Multilayer Hydrogel Microcapsules
}

\author{
Aaron Alford ${ }^{1,+}{ }^{,}$Brenna Tucker ${ }^{1,+}$, Veronika Kozlovskaya ${ }^{1}$, Jun Chen ${ }^{1}$, Nirzari Gupta ${ }^{1}$, \\ Racquel Caviedes ${ }^{1}$, Jenna Gearhart ${ }^{1}$, David Graves ${ }^{1}$ and Eugenia Kharlampieva ${ }^{1,2, *}$ \\ 1 Department of Chemistry, University of Alabama at Birmingham, Birmingham, AL 35294, USA; \\ aaaron@uab.edu (A.A.); batucker@uab.edu (B.T.); vkozlovs@uab.edu (V.K.); cj1016@uab.edu (J.C.); \\ nirzari@uab.edu (N.G.); racquelc@uab.edu (R.C.); gea7026@student.waynesburg.edu (J.G.); \\ dgraves@uab.edu (D.G.) \\ 2 Center of Nanoscale Materials and Biointegration, Birmingham, AL 35294, USA \\ * Correspondence: ekharlam@uab.edu; Tel.: +1-201-934-0974 \\ + These authors contributed equally to this work.
}

Received: 23 November 2018; Accepted: 3 December 2018; Published: 5 December 2018

\begin{abstract}
Nucleic acid therapeutics have the potential to be the most effective disease treatment strategy due to their intrinsic precision and selectivity for coding highly specific biological processes. However, freely administered nucleic acids of any type are quickly destroyed or rendered inert by a host of defense mechanisms in the body. In this work, we address the challenge of using nucleic acids as drugs by preparing stimuli responsive poly(methacrylic acid)/poly(N-vinylpyrrolidone) (PMAA/PVPON) n multilayer hydrogel capsules loaded with $\sim 7 \mathrm{kDa}$ G-quadruplex DNA. The capsules are shown to release their DNA cargo on demand in response to both enzymatic and ultrasound (US)-triggered degradation. The unique structure adopted by the G-quadruplex is essential to its biological function and we show that the controlled release from the microcapsules preserves the basket conformation of the oligonucleotide used in our studies. We also show that the (PMAA/PVPON) multilayer hydrogel capsules can encapsulate and release $\sim 450 \mathrm{kDa}$ double stranded DNA. The encapsulation and release approaches for both oligonucleotides in multilayer hydrogel microcapsules developed here can be applied to create methodologies for new therapeutic strategies involving the controlled delivery of sensitive biomolecules. Our study provides a promising methodology for the design of effective carriers for DNA vaccines and medicines for a wide range of immunotherapies, cancer therapy and/or tissue regeneration therapies in the future.
\end{abstract}

Keywords: multilayer capsules; layer-by-layer; DNA; ultrasound; microcapsules; hydrogen-bonded; hydrogel

\section{Introduction}

Nucleic acids are the universal biological code and dictate the essential processes in all organisms. Owing to their biological relevance, thorough characterization including everything from fundamental structural studies [1,2] to their potential use in a variety of applications has been reported [3-5]. In recent years, the delivery of therapeutic nucleic acids to modify gene expression has emerged as a promising therapeutic method for a range of inherited or acquired diseases [6-8]. Among the multitude of repeating nucleic acid motifs, the human G-quadruplex sequence has emerged as a potentially relevant key to new therapeutic possibilities [9]. The G-quadruplex offers unique DNA structures formed from guanine-rich sequences of DNA that can be found within promotor regions of oncogenes as well as in the telomeric regions of the chromosome [10,11]. G-quadruplex structures 
have particular conformational stabilities that can be observed due to their tendency for the unique secondary structure to assemble from multiple or single-strands of DNA if the repeating GGG motif spans four closely interspersed sequences $[12,13]$. The G-quadruplex structural motif is nuclease resistant, plays a role in transcriptional regulation, and is structurally similar to the thrombin binding aptamer (TBA) [14,15], which is itself a G-quadruplex forming a sequence of DNA that is commonly used as an anti-coagulant during surgeries $[16,17]$. As G-quadruplex formations can be found in the telomeric chromosomal region, and chromosomes with damaged or shortened telomeres can cause miscoding that may result in cancerous cells [9], delivery of G-quadruplex DNA is being investigated as a component of gene-mediated anticancer treatment $[18,19]$. Despite their potential, nucleic acid therapeutics as disease treatment strategies have not been widely adopted due to the series of extracellular and intracellular barriers preventing effective delivery of nucleic acids to the desired sites [7]. When free DNA is administered as a therapeutic agent, it can be rapidly degraded by nucleases in the plasma or the extracellular matrix [20]. In addition, non-degraded DNA is rapidly cleared from circulation with high likelihood [21], while the lack of endosomal escape, degradation by lysosomes [22], and insufficient cytosolic transport represent more specific obstructions to therapeutic efficacy if the DNA can be internalized by cells $[23,24]$. In response to these challenges, both viraland non-viral vectors have been suggested as a way to increase therapeutic potential by providing assistance for intracellular transport and release of DNA at the target site $[25,26]$. The promising natural efficiency of viral vectors has encouraged recent studies on their development. However, several limitations have been associated with the use of viral vectors including low capacity, challenges in scale-up, high cost, and risk of mutagenesis $[27,28]$. Furthermore, vector-inactivating immune responses are frequently observed with repeated administrations or prior exposures, which limits the efficacy of these drugs [7]. Non-viral vectors synthesized from a variety of different cationic lipids or polymers can condense the DNA into micro- or nanoparticles and offer a reprieve from the limitations of viral vectors [24]. While synthetically simple and commercially available, cationic non-viral vectors such as Lipofectamine 2000 and polyethyleneimine (PEI) have been shown to cause cytotoxicity [24,29], and it has also been discussed that the direct conjugation of non-viral vectors to DNA may change the native properties and functions of the nucleic acid sequence [30]. Furthermore, while liposomal and microbubble-based delivery systems have been shown to utilize ultrasound (US) to release encapsulated gene therapeutics [31,32], these strategies still suffer from low release efficiency and inconsistent results [33]. Consequently, it is of significant importance to develop a safe and biocompatible non-viral vector that can encapsulate DNA inside an inert carrier without changing the structural integrity of the DNA while still offering an effective, controllable release mechanism.

The layer-by-layer (LbL) assembly of polymers at surfaces has widely been demonstrated as a useful method to engineer thin coatings, hollow capsules, and network hydrogels for various therapeutic and preventative strategies owing to the nanoscale control over thickness, architecture, and chemistry of the materials [34,35]. The LbL assembly allows for the design of hybrid materials that incorporate both synthetic and biomolecules in their architecture. For example, Lvov et al. demonstrated that negatively charged DNA could be incorporated into LbL multilayers by electrostatic interactions with positively charged cationic polymers as building blocks [36-38]. The ability of LbL multilayers to not only incorporate but also release potentially therapeutic DNA has been the focus of recent studies [39]. Lynn et al. has recently shown the release of plasmid DNA from LbL multilayers via film erosion or contact transfer from mixed multilayers of ester and charge transfer polymers, or electrostatically-assembled systems of poly(acrylic acid)/polyethyleneimie (PAA/PEI), respectively [40,41]. The Hammond group has also shown multilayer coatings for the delivery of CTGF (connective tissue growth factor)-silencing siRNA with the aim of reducing scar formation in burn treatments [42]. While the studies mentioned above showcase the remarkable ability of LbL systems to incorporate and release DNA through a variety of novel pathways, they are focused on flat 2D films and surface coatings, which may not translate to therapeutic strategies involving injected therapeutic agents that reach targets in the body through circulation. 
In response to this limitation, 3D micro- and nanoparticles that incorporate therapeutic DNA have been the subject of recent development in LbL systems $[43,44]$. These LbL-assembled polymer microcapsules are promising non-viral vectors for drug delivery due to their biocompatibility, micron-sized interior cavity which enables high loading capacity, and potential for targeted delivery of their cargo [30,45-47], having been used as model vehicles for encapsulation of DNA within the hollow cavity or the shell of the capsule $[48,49]$. Through selection of polymer type, molecular weight, and crosslink chemistry, the nanothin shells of LbL hydrogel microcapsules can be tailored for controlled cargo release via stimuli including $\mathrm{pH}$, temperature, and US irradiation [50-52]. The LbL assembly process also enables association between the capsules and their cargo as well as the type and degree of response to stimuli [53]. Well-documented strategies by Caruso et al. and Sukorukhov et al. approach incorporating DNA within the interior of degradable microcapsules by loading DNA into calcium carbonate microparticles followed by coating of LbL multilayers with enzyme degradable crosslinks and dissolution of the inorganic templates [54-57]. A recent report has also described delivery of plasmid DNA via passive transfection of DNA-loaded LbL silk microparticles into NIH/3T3 fibroblasts [58].

Though the feasibility of DNA encapsulation is evident from the above studies, they have mostly been focused on enzymatic degradation, which may be limited by the conditions of the target environment. Therefore, the encapsulation and efficient multiresponsive release of a promising DNA target such as G-quadruplex-forming sequences via enzyme and US-mediated capsule destruction represents a significant advancement in the field of controlled delivery of gene therapeutics but has yet to be reported in the field. In addition, conservation of the critically-important secondary structure of DNA after undergoing the conditions of the release mechanism has yet to be demonstrated. Finally, while enzyme-triggered release has been demonstrated to be efficient, gene vectors that are responsive to US in addition to intracellular redox environments offer the best approach to improving overall efficacy, as it has been widely demonstrated that unfavorable cell membrane crossing of microparticles and small drugs can be greatly assisted by the US-exclusive sonoporation effect [59-62].

We have recently reported that PMAA hydrogel particles crosslinked with the enzyme-degradable crosslinker cystamine can release the anticancer drug doxorubicin (DOX) upon introduction of intracellular concentrations of glutathione (GSH) [63,64]. We have also shown with hydrogen-bonded tannic acid/poly(N-vinylpyrrolidone) (TA/PVPON) multilayer microcapsules that the assembly conditions and US dose can be customized to tailor their susceptibility to US irradiation, releasing the same drug in sustained or burst-type dosing in vitro and in vivo $[65,66]$. US has been widely used in gene delivery because the stimulation offers a traceable, localized and non-invasive way to release therapeutic cargos. More importantly, US has been shown to assist in brain uptake of DNA [67], enhance microbubble mediated gene delivery [68], and increase the permeation of therapeutics into target cells $[69,70]$. In addition to the type of stimulus applied to microcapsule drug carriers, an important parameter controlling the encapsulation and release of therapeutic cargo is the pore size of the shell network. Regarding this, we have shown that hollow microcapsules with shells made of interpenetrated networks of PMAA/PVPON are capable of efficiently loading and releasing hydrophilic model therapeutics from among a wide range of molecular weights [71]. While we demonstrated the use of this new system for low molecular weight $\left(M_{\mathrm{W}}<1000 \mathrm{Da}\right)$ small molecules, we now show that the microcapsules with interpenetrated PMAA/PVPON shell networks allow efficient loading and precisely controlled release of nucleic acid oligomers and longer double stranded sequences.

In the current work, we study the conditions for fabrication of PMAA/PVPON multilayer hydrogel microcapsules using porous $\mathrm{CaCO}_{3}$ sacrificial templates as well as the encapsulation and controlled release of two types of nucleic acids (G-quadruplex and double-stranded calf thymus) through US irradiation and GSH exposure. We show that the (PMAA/PVPON) multilayer hydrogel capsules can encapsulate and release both $\sim 450 \mathrm{kDa}$ double stranded DNA and shorter $\sim 7 \mathrm{kDa}$ G-quadruplex oligonucleotides. The (PMAA/PVPON) multilayer hydrogel was chosen due to the 
biocompatibility of the polymers used for fabrication of various drug carrier constructs [63,72-74]. To our knowledge, this is the first example of multi-responsive multilayer microcapsules with the capability of G-quadruplex DNA delivery and preservation of the critical secondary structure after release. Our approach may provide a promising methodology for the design of effective carriers for DNA vaccines and medicines for a wide range of immunotherapies, cancer therapy and/or tissue regeneration therapies in the future.

\section{Materials and Methods}

\subsection{Materials}

Poly(methacrylic acid) (PMAA, average $M_{\mathrm{W}} 100,000 \mathrm{Da}$ ), poly( $N$-vinylpyrrolidone) (PVPON, average $M_{\mathrm{w}} 1,300,000 \mathrm{Da}$ ), poly(ethyleneimine) (PEI; average $M_{\mathrm{W}} 70,000 \mathrm{Da}$ ), L-glutathione reduced (GSH), and cystamine dihydrochloride (CS) were purchased from Sigma-Aldrich (St. Louis, MO, USA). 1-ethyl-3-(3-(dimethylamino)propyl)-carbodiimide hydrochloride (EDC) was purchased from Chem-Impex International (Wood Dale, IL, USA). Monobasic sodium phosphate $\left(\mathrm{NaH}_{2} \mathrm{PO}_{4}\right)$, dibasic sodium phosphate $\left(\mathrm{Na}_{2} \mathrm{HPO}_{4}\right)$, ethylenediaminetetraacetic acid sodium salt (EDTA), sodium chloride ( $\mathrm{NaCl})$, calcium chloride $\left(\mathrm{CaCl}_{2}\right)$, sodium carbonate $\left(\mathrm{Na}_{2} \mathrm{CO}_{3}\right)$, ethidium bromide, and calf thymus DNA (ctDNA) were purchased from Fisher Scientific (Hampton, NH, USA). DNA oligonucleotides (5'-AGGGTTAGGGTTAGGGTTAGGG-3') were purchased from Midland Certified Reagents (Midland, TX, USA).

\subsection{Preparation of Double-stranded Calf Thymus DNA}

Calf thymus DNA was dissolved in $0.01 \mathrm{M} \mathrm{NaH}_{2} \mathrm{PO}_{4}, 0.01 \mathrm{M} \mathrm{Na}_{2} \mathrm{HPO}_{4}, 0.001 \mathrm{M}$ EDTA (BPE) buffer at $4{ }^{\circ} \mathrm{C}$ overnight before sonication using a Branson sonifier (Danbury, CT, USA) for 5 min on/off intervals for a total of $30 \mathrm{~min}$. The DNA was kept over an ice bath and nitrogen gas was bubbled through the sample throughout the sonication process. A syringe filter $(0.45 \mu \mathrm{m})$ was used to filter the sonicated solution and the salt concentration was increased to $0.2 \mathrm{M}$ by the addition of $\mathrm{NaCl}$. The DNA sample was treated with RNase at $37^{\circ} \mathrm{C}$ for $30 \mathrm{~min}$ followed by treatment with proteinase $\mathrm{K}$ at $37^{\circ} \mathrm{C}$ for $2 \mathrm{~h}$. The DNA sample was extracted with an equal volume of chloroform in a separatory funnel before being split into two $50-\mathrm{mL}$ Falcon tubes. The tubes were centrifuged at $4{ }^{\circ} \mathrm{C}$ for $5 \mathrm{~min}$ and the top layers from each tube were added back to the separatory funnel. This process was repeated until the interface between the DNA solution and the chloroform was clear. The DNA layers were then pooled together and precipitated by adding salt-saturated ethanol to the solution. The precipitated DNA was separated by centrifugation and dried in vacuo. The resulting DNA pellet was dissolved in BPES buffer $\left(0.01 \mathrm{M} \mathrm{NaH}_{2} \mathrm{PO}_{4}, 0.01 \mathrm{M} \mathrm{Na}_{2} \mathrm{HPO}_{4}, 0.001 \mathrm{M}\right.$ EDTA, $\left.0.150 \mathrm{M} \mathrm{NaCl}\right)$ and dialyzed against BPES buffer. After a minimum of 4 buffer changes, the DNA was collected from dialysis, filtered again using a $0.45 \mu \mathrm{m}$ syringe filter, and stored at $4{ }^{\circ} \mathrm{C}$ for future use. The average length of the calf thymus DNA was determined by an agarose gel to be approximately 700 base pairs, or $\sim 450 \mathrm{kDa}$. The concentration of the DNA sample per duplex was determined by monitoring the UV-Vis absorbance at $260 \mathrm{~nm}\left(\varepsilon=13,200 \mathrm{M}^{-1} \cdot \mathrm{cm}^{-1}\right.$ (base pairs)).

\subsection{Preparation of DNA Oligonucleotides}

G-quadruplex forming oligonucleotides were resuspended in sodium phosphate buffer $(50 \mathrm{mM}$ $\mathrm{NaH}_{2} \mathrm{PO}_{4}, 50 \mathrm{mM} \mathrm{Na} 2 \mathrm{HPO}_{4}, 150 \mathrm{mM} \mathrm{NaCl}$, and $0.01 \mathrm{mM}$ EDTA) and stored at $4{ }^{\circ} \mathrm{C}$ overnight. The G-quadruplex was allowed to form by heating the dissolved DNA to $90{ }^{\circ} \mathrm{C}$ and allowing it to cool at a rate of $0.1^{\circ} \mathrm{C}$ per minute to ambient temperature before refrigeration. The concentration of DNA per strand of G-quadruplex was assessed by measuring the absorbance at $260 \mathrm{~nm}$ at room temperature $\left(\varepsilon=228,500 \mathrm{M}^{-1} \cdot \mathrm{cm}^{-1}\right.$ (strand)). When not in use, oligonucleotide solutions were stored at $4{ }^{\circ} \mathrm{C}$. 


\subsection{Encapsulation of DNA into Calcium Carbonate Microparticles}

G-quadruplex oligonucleotides were encapsulated into porous calcium carbonate microparticles by combining $150 \mu \mathrm{L} \mathrm{CaCl}$ solution $(1 \mathrm{M}), 1190 \mu \mathrm{L}$ ultrapure water, and $10 \mu \mathrm{L}$ of $1 \mathrm{mM}$ DNA solution with $150 \mu \mathrm{L} \mathrm{Na}_{2} \mathrm{CO}_{3}(1 \mathrm{M})$ under rapid stirring for $40 \mathrm{~s}$. G-quadruplex-loaded microparticles were removed from the stir plate, centrifuged to remove the supernatant, and washed by adding ultrapure water and vortexing the sample. The G-quadruplex-loaded cores were washed with water a second time and examined with optical microscopy to determine their size and ensure they had not fused or aggregated. The supernatants from the wash step were saved for further analysis of the capsule loading capacity of G-quadruplex. Empty cores were also prepared using this same strategy.

Double stranded calf thymus DNA was encapsulated by mixing $450 \mu \mathrm{L} \mathrm{CaCl}_{2}(1 \mathrm{M}), 2.07 \mathrm{~mL}$ ultrapure water, and $450 \mu \mathrm{L}$ ctDNA $(6.1 \mathrm{mM})$. Once this solution spun uniformly, $450 \mu \mathrm{L} \mathrm{Na}{ }_{2} \mathrm{CO}_{3}$ $(1 \mathrm{M})$ was added and after $40 \mathrm{~s}$, the cores were collected and washed as described above. To make the control (empty) calcium carbonate cores for this system, $450 \mu \mathrm{L}$ of sodium phosphate buffer was added instead of the ctDNA.

\subsection{Synthesis of G-Quadruplex-Loaded (PMAA/PVPON) ${ }_{n}$ Multilayer Hydrogel Capsules}

The spherical DNA-loaded calcium carbonate templates were shaken with an aqueous solution of $1 \mathrm{mg} / \mathrm{mL}$ PEI to assist entrapment of DNA and to enhance binding of the polymers to the surface. Alternating adsorption of PMAA or PVPON from polymer solutions $(0.25 \mathrm{mg} / \mathrm{mL}$ in $0.01 \mathrm{M} \mathrm{PO}_{4}$ at $\mathrm{pH}$ 4) was performed starting from PMAA with 10 min-deposition time followed by centrifugation to exchange the supernatant for buffer and rinse nonadsorbed polymer. After triplicate rinsing, PVPON solution was added and the deposition process was repeated until the desired number of (PMAA/PVPON) polymer bilayers had been deposited. After complete polymer deposition, (PMAA/PVPON) core-shells were allowed to shake with 1-ethyl-3-(3-(dimethylamino)propyl)-carbodiimide hydrochloride (EDC) $(5 \mathrm{mg} / \mathrm{mL}, \mathrm{pH} 5.5)$ for $30 \mathrm{~min}$ before being crosslinked with cystamine dihydrochloride $(5 \mathrm{mg} / \mathrm{mL}, \mathrm{pH} 5.5)$ for $48 \mathrm{~h}$. The cross-linked core-shells were washed twice with buffer $\left(\mathrm{NaH}_{2} \mathrm{PO}_{4}, \mathrm{pH}\right.$ 5.5) before EDTA (1 mM, pH 5.5) was added to dissolve the cores. The dissolution of the $\mathrm{CaCO}_{3}$ templates was followed via optical microscopy and scanning electron microscopy (SEM). Once the spherical templates had dissolved, the (PMAA/PVPON $)_{n}$ capsules were washed and dialyzed against $0.01 \mathrm{M}$ phosphate buffer ( $\mathrm{pH}$ 7.4). After $72 \mathrm{~h}$, capsules were removed from dialysis, washed with phosphate buffer ( $\mathrm{pH} 7.4)$, and stored for study.

\subsection{Characterization of (PMAA/PVPON $)_{13}$ Capsules Using Fourier Transform Infrared Spectroscopy (FTIR)}

FTIR was used to analyze the chemical composition of PMAA/PVPON capsules. Empty and G-quadruplex-loaded (PMAA/PVPON) 13 hydrogel capsules at pH 7.5 as well as G-quadruplex forming oligonucleotides at $\mathrm{pH} 7.5$ were used to assess the location of nucleotides in the capsule shell. To prepare the samples for FTIR, $0.5 \mathrm{~mL}$ of each at $\mathrm{pH} 7.5$ were freeze-dried overnight. Spectra were collected in absorbance mode using a Bruker Alpha-FTIR (ATR-FTIR) (Billerica, MA, USA). The number of scans collected for each of the background and sample measurements equaled 128 . The resulting spectra were normalized and baseline corrected.

\subsection{Characterization of (PMAA/PVPON $)_{n}$ Capsules by SEM and Confocal Laser Scanning Microscopy (CLSM)}

A FEI Quanta FEG SEM microscope (Hillsboro, OR, USA) at $10 \mathrm{kV}$ was used to image dried suspensions of G-quadruplex-loaded (PMAA/PVPON) capsules. Capsules were dialyzed against DI water to prepare them for SEM, and a drop of the diluted capsule solution was placed on a silicon wafer and allowed to dry overnight. A Denton sputter-coater was used to coat the dried capsule samples with a $\sim 5 \mathrm{~mm}$ thick layer of silver immediately before imaging. For CLSM imaging, $30 \mu \mathrm{L}$ 
of the $1.6 \times 10^{8}$ capsules $/ \mathrm{mL}$ stock solution was pipetted into Lab-Tek confocal microscopy (EMS, Hatfield, PA, USA) chambered coverglass containing buffer solutions. A $10 \mu \mathrm{L}$ aliquot of Alexa Flour 568 hydrazide $(0.5 \mathrm{mg} / \mathrm{mL})$ fluorescent dye solution was added to assist in visualizing the capsules and the capsules were allowed to settle overnight before imaging with a Nikon A1R multiphoton confocal microscope (Tokyo, Japan) equipped with a $60 \times$ oil immersion objective.

\section{8. Ђ-potential Measurements of (PMAA/PVPON $)_{n}$ Multilayer Hydrogel Capsules}

A Malvern Nano Zetasizer (Spectris, Egham, United Kingdom) was used to measure the $\zeta$-potential of the G-quadruplex-loaded $(\mathrm{PMAA} / \mathrm{PVPON})_{\mathrm{n}}$ capsules in the presence of $0.01 \mathrm{M}$ phosphate buffer solutions with $\mathrm{pH}$ values from $\mathrm{pH}=3$ to 7.4. The capsules were allowed to equilibrate for $10 \mathrm{~min}$ before being vortexed and inserted into the sample chamber. The $\zeta$-potential was determined by taking the average of three sets of 20 individual measurements.

\subsection{US-Controlled Release of G-Quadruplex DNA from the (PMAA/PVPON) ${ }_{n}$ Capsules}

G-quadruplex-loaded (PMAA/PVPON)n capsules with the bilayer number of $n=13$ or 6 were burst using a Fisher 120 sonic dismembrator at $22 \mathrm{kHz}, 14$ or $55 \mathrm{~W} / \mathrm{cm}^{2}$ in $20 \mathrm{~s}$ bursts. The sonication probe was inserted into the capsule solution and moved throughout the volume of the centrifuge tube throughout the 20-s treatment. The capsule fragments were centrifuged for $15 \mathrm{~min}$ at $8000 \mathrm{rpm}$, and the supernatant removed for UV spectroscopic analysis using the absorbance wavelength of $260 \mathrm{~nm}$. Water and $70 \%$ ethanol were used to wash the sonication probe before and after use.

\subsection{Turbidimetry of GSH-Treated (PMAA/PVPON) ${ }_{13}$ Capsules}

Turbidity measurements were performed to track the GSH-induced degradation of (PMAA/PVPON) 13 capsules at $37{ }^{\circ} \mathrm{C}$ using fluorescence spectroscopy (Varian, Palo Alto, CA, USA, Cary Eclipse). The scattering intensity of the capsules suspended in phosphate buffer $(2 \times$ $10^{5}$ capsules/ $\mu \mathrm{L}$ ) at $\mathrm{pH} 7.4$ with or without $5 \mathrm{mM} \mathrm{GSH}$ was measured at $\lambda=700 \mathrm{~nm}$ [75]. The ratio of the particle scattering intensity at a certain interval to that of the initial nondegraded particles was used to calculate the relative turbidity.

\subsection{Quantification of G-Quadruplex DNA Release}

Prior to the US/enzyme treatment, the capsules were centrifuged (8000 rpm for $30 \mathrm{~min}$ ) and the supernatant was collected, and monitored for absorbance at $260 \mathrm{~nm}$ with a Varian Cary 50 UV-Vis spectrometer (Palo Alto, CA, USA) in a quartz cuvette to determine any initial amounts of G-quadruplex present, and then returned to the capsules. After US/enzyme treatment, the release of G-quadruplex was determined using the absorbance at $260 \mathrm{~nm}$ and the molar absorptivity coefficient $\left(228,500 \mathrm{M}^{-1} \cdot \mathrm{cm}^{-1}\right.$ (strand)) of the G-quadruplex oligomers.

\subsection{Quantification of $d s D N A$ Release}

The amount of dsDNA released from the capsules was determined through fluorescence measurements of DNA-loaded capsules after US treatment. Samples were excited at $520 \mathrm{~nm}$ and the emission spectrum was recorded from 530 to $750 \mathrm{~nm}$. A $1 \mathrm{~mm} \times 1 \mathrm{~mm}$ square cuvette was used for all measurements and a $1 \% v / v$ amount of ethidium bromide $(\mathrm{EtBr})$ was added to each sample before collecting the emission data. Samples equilibrated for $10 \mathrm{~min}$ before data collection. A calibration curve was collected for systematically increasing amounts of dsDNA and the emission at $605 \mathrm{~nm}$ was used to calculate the dsDNA concentration in each sample.

\subsection{Probing Structural Changes of G-Quadruplex DNA after Release}

DNA released from the capsules was examined for any changes to the secondary structure using circular dichroism (CD) spectroscopy. CD scans of free G-quadruplex were compared to released 
DNA from both the $\mathrm{CaCO}_{3}$ cores and the (PMAA/PVPON) capsules to determine any changes to the secondary structure. Free and released G-quadruplex scans were obtained from an average of 3 scans collected from 320-220 $\mathrm{nm}$ with a 1-nm step and a 1-s response time.

\section{Results and Discussion}

\subsection{Synthesis of (PMAA/PVPON $)_{n}$ Hydrogel Capsules Using Calcium Carbonate Sacrificial Templates}

One of the characteristic properties of PMAA multilayer hydrogels is their ability to undergo dramatic volume transitions upon ionization of the PMAA carboxylates and subsequent influx of counterions. We have previously shown that both (PMAA) $n$ multilayer hydrogel particles and hollow multilayer hydrogel capsules can swell up to two times their size $[51,63,74]$ in response to $\mathrm{pH}$ change from the isoelectric point of the crosslinked network $(\sim \mathrm{pH}=5)$ to $\mathrm{pH}=7.4$, in addition to mild swelling at lower $\mathrm{pH}$ due to single-side reacted free amine groups from the diamine crosslinker. In these previous studies, complete removal of PVPON was ensured to achieve a single component PMAA multilayer hydrogel. However, the presence of PVPON in the (PMAA/PVPON) crosslinked multilayer and the additional chain entanglement between PMAA and PVPON components can suppress the swelling of the PMAA network. We demonstrated in a recent study that increasing the molecular weight of PVPON within cross-linked PMAA multilayer hydrogel films obtained by spin-assisted multilayer assembly decreases the ability of the PVPON to be released from the network after the $\mathrm{pH}$ is increased above the $\mathrm{p} K_{\mathrm{a}}$ of PMAA [76]. Specifically, when the molecular weight of PVPON in PMAA/PVPON hydrogen-bonded multilayer template films was increased to 1,300,000 Da (1300 kDa), only $18 \%$ of the PVPON content was released due to the increased chain entanglement in comparison to shorter (58 kDa) PVPON polymer chains [76]. In another recent study, we have demonstrated that hydrogel capsules made of interpenetrated (PMAA/PVPON) multilayers can be obtained by dipped multilayer assembly of PMAA $\left(M_{\mathrm{w}}=150,000 \mathrm{Da}\right)$ and PVPON $\left(M_{\mathrm{w}}=1,300,000 \mathrm{Da}\right)$ on porous and solid silica microparticles followed by chemical crosslinking of PMAA [71]. Because of its high molecular weight, PVPON was physically entrapped within the PMAA network and did not diffuse out from the network at $\mathrm{pH}=8$ [71]. In our current work, we utilized high molecular weight PMAA $(100 \mathrm{kDa})$ and PVPON $(1300 \mathrm{kDa})$ to create capsules of (PMAA/PVPON $)_{\mathrm{n}}$ interpenetrated multilayer hydrogel using sacrificial porous calcium carbonate particles with the aim of increasing the retention of loaded DNA molecules. The subscript $n$ denotes the number of polymer bilayers. Figure 1 shows a schematic overview of the synthesis of nucleic acid-loaded capsules.

Complete dissolution of the calcium carbonate cores and the presence of the unruptured polymer shell were confirmed by SEM. Figure 2a demonstrates the dehydrated hollow capsule shell collapsed on the surface of silicon wafer and was devoid of any fragments of the inorganic core template. Figure $2 \mathrm{~b}, \mathrm{c}$ show confocal microscopy images of (PMAA/PVPON) 6 hydrogel capsules crosslinked with cystamine for $24 \mathrm{~h}$ (Figure $2 \mathrm{~b}$ ) and $48 \mathrm{~h}$ (Figure 2c) and the average diameters of the capsules at $\mathrm{pH}$ values increasing from $\mathrm{pH}=3$ to $\mathrm{pH}=8$ are shown in Figure 2d,e. 


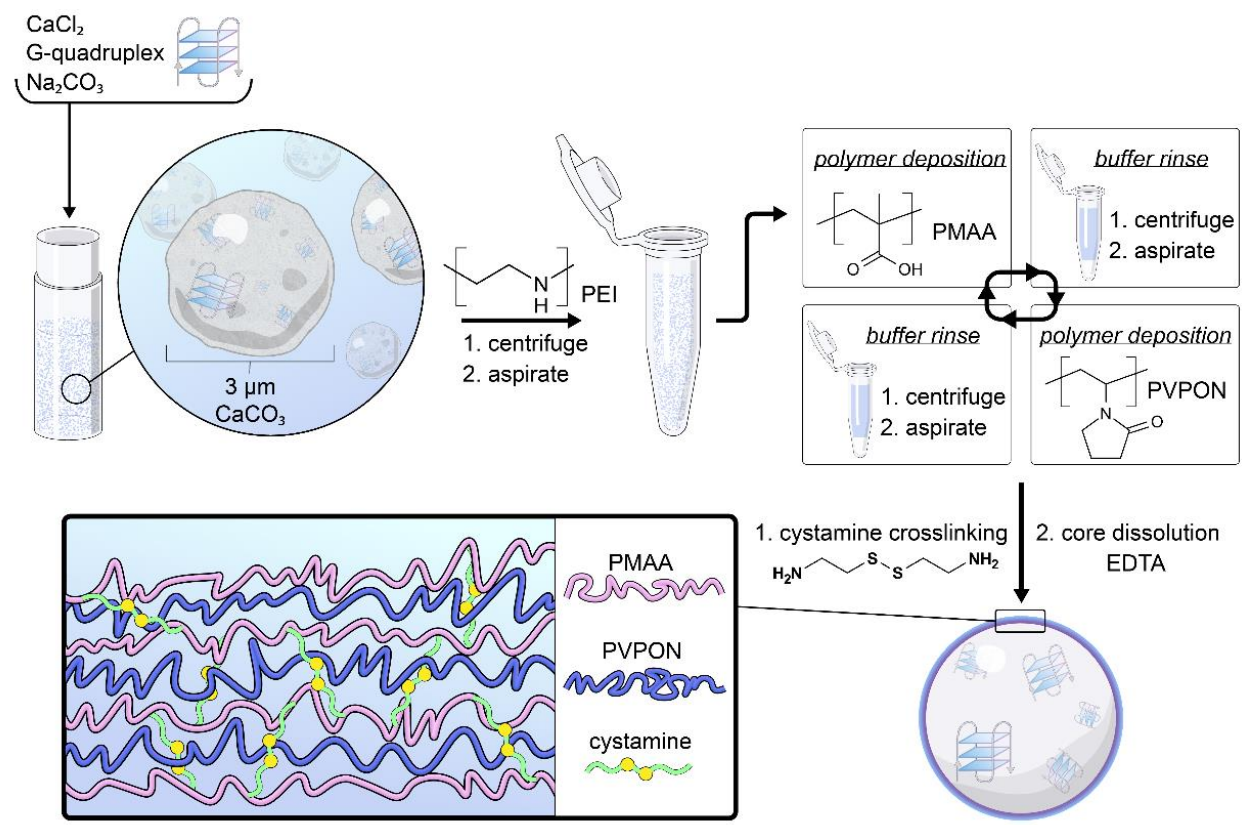

Figure 1. Fabrication of the (PMAA/PVPON $)_{n}$ multilayers. The DNA-loaded (PMAA/PVPON $)_{n}$ microcapsules were prepared by co-precipitation of $\mathrm{Na}_{2} \mathrm{CO}_{3}$ and $\mathrm{CaCl}_{2}$ salts with G-quadruplex or dsDNA in aqueous solution. PEI was adsorbed onto particle surfaces to increase interaction with the first PMAA layer. PMAA and PVPON were alternatingly adsorbed onto particles surfaces until the desired number of bilayers (n) was formed. The core-shells were crosslinked with cystamine before dissolving the sacrificial template in EDTA, resulting in hollow DNA-loaded multilayer hydrogel microcapsules.
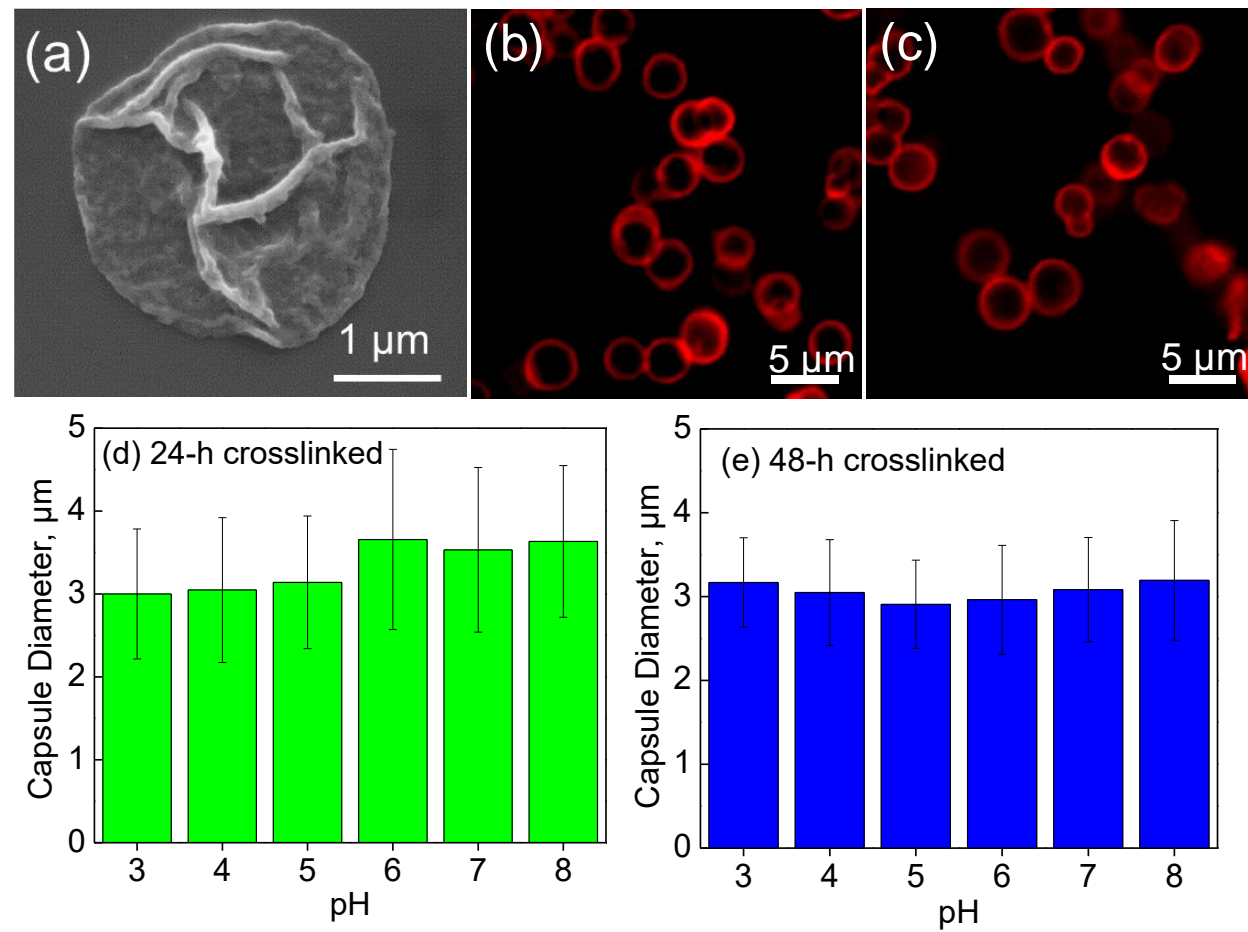

Figure 2. (a) SEM image of (PMAA/PVPON) 13 multilayer hydrogel capsules. CLSM images of (PMAA/PVPON) 6 hydrogel capsules crosslinked for (b) $24 \mathrm{~h}$ and (c) $48 \mathrm{~h}$ imaged in solution at $\mathrm{pH}$ 4. Average diameters of the capsules crosslinked for 24 (d) and 48 (e) hours as a function of $\mathrm{pH}$ as obtained from analysis of their CLSM images using ImageJ software (version 1.52e, NIH, Bethesda, $\mathrm{MD}, \mathrm{USA}$ ). The data is presented as mean \pm standard deviation (SD). For each measurement series, at least 30 capsules were analyzed for each $\mathrm{pH}$ value. 
CLSM analysis in Figure 2d,e shows that the average size of the crosslinked (PMAA/PVPON) 13 hydrogel capsules remained unchanged when the 24-h and 48-h crosslinked capsules were exposed to solutions with $\mathrm{pH}$ values increasing from $\mathrm{pH}=3$ to $\mathrm{pH}=8$. For example, the average size of the capsules crosslinked for $24 \mathrm{~h}$ was $3.0 \pm 0.5$ and $3.6 \pm 0.7 \mu \mathrm{m}$, at $\mathrm{pH}=3$ and $\mathrm{pH}=8$, respectively. As reported previously, the cystamine-crosslinked PMAA network demonstrated $\mathrm{pH}$-dependent swelling at $\mathrm{pH}>6$ and $\mathrm{pH}<5$ because of ionization of carboxylic and amine groups, respectively, similar to that observed for PMAA multilayer hydrogels cross-linked with ethylenediamine [34,63]. However, we have shown earlier that the entrapment of PVPON within the capsule wall as well as a high crosslink density can drastically change the $\mathrm{pH}$-swelling profile of (PMAA/PVPON) hydrogels [71]. Thus, the presence of long PVPON chains highly entangled within the PMAA capsule hydrogel shell was shown to suppress mobility of PMAA segments between the crosslinks.

Conversely, the $\mathrm{pH}$-induced swelling of (PMAA/PVPON) hydrogel capsules was shown to be almost independent of capsule crosslinking time because the swelling was mostly controlled by the presence of the PVPON [71]. Indeed, the capsule swelling suppression by entangled PVPON chains was observed in this work when more tightly crosslinked capsules (48-h crosslinked (PMAA/PVPON) 13 ) were exposed to solutions of various $\mathrm{pH}$ values. Figure 2e shows that the average capsule size of 48-h crosslinked (PMAA/PVPON) 13 hydrogel shells was $3.2 \pm 0.8$ and $3.2 \pm 0.9 \mu \mathrm{m}$ when exposed to $\mathrm{pH}=3$ and $\mathrm{pH}=8$, respectively. This data indicate that extensive crosslinking of the PMAA network resulted in entrapment of the PVPON chains already after the 24-h crosslinking time. Despite that, the 48-h crosslinked capsules were chosen for loading of nucleic acid molecules as the lowered mesh size of the network afforded by entrapped PVPON and a higher crosslinking density can also help to constrain the permeation of DNA through the shell in the absence of release stimuli.

\subsection{Encapsulation of Nucleotides into (PMAA/PVPON $)_{n}$ Hydrogel Capsules}

FTIR analysis was used to determine chemical composition of the hydrogel capsules after dissolution of calcium carbonate cores. For that, both empty (control) and G-quadruplex-loaded $(\mathrm{PMAA} / \mathrm{PVPON})_{13}$ hydrogel capsules were lyophilized from solution at $\mathrm{pH}=7.4$ before analysis. Figure 3 shows that the FTIR spectrum for the empty (PMAA/PVPON) 13 hydrogel capsules (top panel; red trace) reveals major peaks centered around $1525 \mathrm{~cm}^{-1}$ and $1640 \mathrm{~cm}^{-1}$ corresponding to the presence of both the ionized carboxylate groups from PMAA $\left(1550 \mathrm{~cm}^{-1}\right)$ and the carbonyl groups of PVPON $\left(1645 \mathrm{~cm}^{-1}\right)$ [77]. The presence of the carbonyl stretch from the lactam ring in PVPON indicates that PVPON is not released from the PMAA network after crosslinking and dissolution of the cores, and remains trapped within the PMAA network. The entrapment of PVPON within the PMAA network is favored by the hydrogen bonding interactions between PMAA and PVPON layers at the crosslinking reaction condition ( $\mathrm{pH} 5-5.8$ ), which is close to that of the $\mathrm{pK}_{\mathrm{a}}$ of PMAA ( 5) [35].

Interestingly, when the capsules were loaded with G-quadruplex DNA, a broadening of the spectral peaks occurred as can be seen in the top panel in Figure 3 (black trace). The FTIR spectrum for the G-quadruplex-loaded capsules contains discernable shoulders, and the presence of PMAA and PVPON can still be detected at 1550 and $1645 \mathrm{~cm}^{-1}$, respectively, within the broadened peak. To discern the reason for this peak broadening, G-quadruplex-forming oligonucleotides were also freeze-dried at $\mathrm{pH}=7.4$ and analyzed with FTIR as shown in Figure 3 (bottom panel). The spectrum for the free oligonucleotide showed a broad peak centered around $1700 \mathrm{~cm}^{-1}$ corresponding to carbonyl groups in the guanine bases of the DNA [78]. This peak can also be seen in Figure 3 (top panel) in the black trace for the G-quadruplex-loaded capsules. 


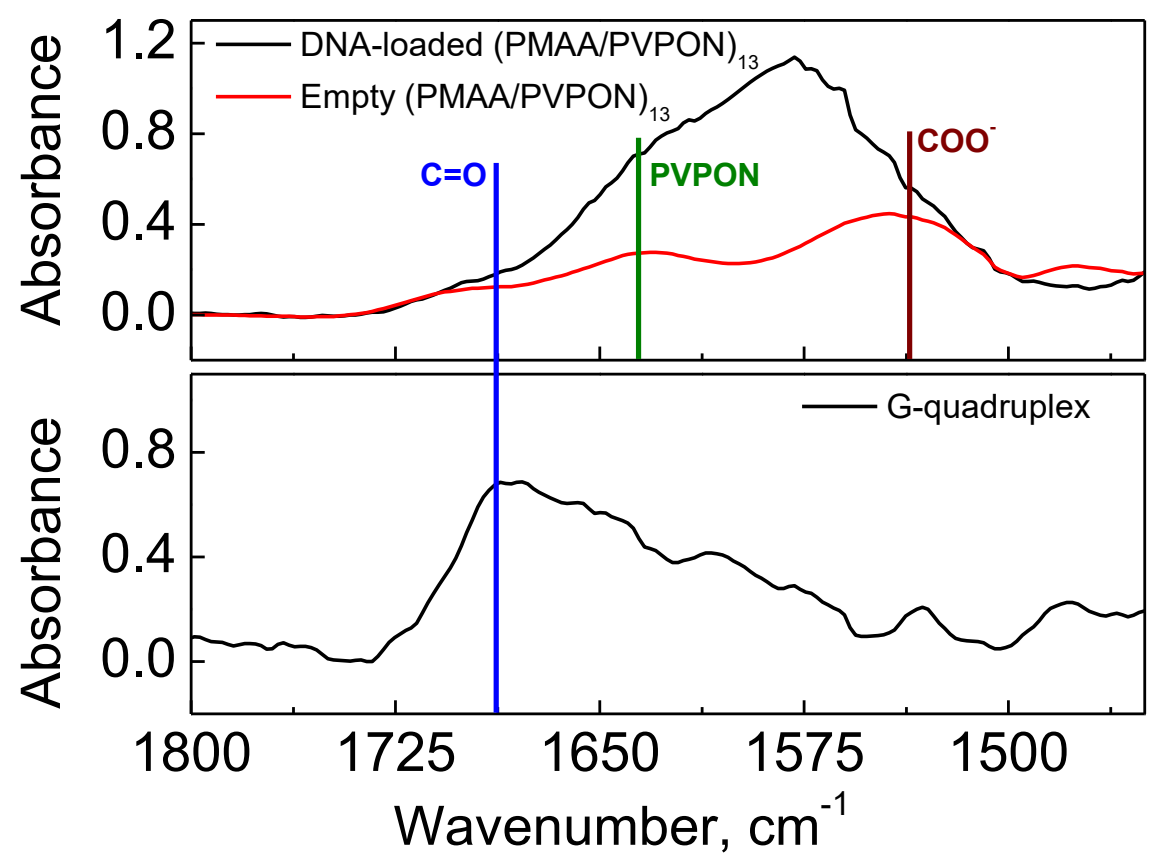

Figure 3. FTIR spectra of (top; red trace) empty and (top; black trace) G-quadruplex DNA-loaded (PMAA/PVPON) 13 multilayer hydrogel capsules; and (bottom; black trace) non-encapsulated G-quadruplex oligonucleotides.

We also found that some of encapsulated G-quadruplex DNA is also present within the (PMAA/PVPON) hydrogel shell. Figure 4 shows the $\mathrm{pH}$-dependent changes of the capsule surface charge. At $\mathrm{pH}=7.4$, the empty (PMAA/PVPON) 13 hydrogel capsules exhibit a negative zeta-potential of $-32 \pm 1 \mathrm{mV}$, while at $\mathrm{pH}=3$ the zeta-potential is completely reversed to a positive value of $25 \pm 2 \mathrm{mV}$ (Figure 4a). At $\mathrm{pH}=4$, the overall capsule surface charge becomes neutral, where the negatively charged ionized carboxylic groups are counteracted by protonated positively charged amine groups from single-side reacted amine crosslinks within the PMAA network as we showed earlier [63]. At higher $\mathrm{pH}$ values, the carboxylic acids are ionized to carboxylates consistent with the observed negative zeta-potential, which is in agreement with our previously reported data [63]. Figure 3b compares the $\mathrm{pH}$-dependent capsule surface charge at the biologically relevant $\mathrm{pH}$ values of 5.5 and 7.5 for both empty and G-quadruplex-loaded capsules measured at the same concentration of the capsule solutions. Both types of capsules possess a negative surface charge at $\mathrm{pH}=5.5 \mathrm{and} \mathrm{pH}=7.5$, with the zeta-potential values of $-18.2 \pm 0.3 \mathrm{mV}$ and $-33 \pm 1 \mathrm{mV}$ for the empty (PMAA/PVPON) 13 hydrogel capsules at $\mathrm{pH}=5.5$ and $\mathrm{pH}=7.5$, respectively; and of $-29.1 \pm 0.7 \mathrm{mV}$ and $-48.5 \pm 0.3 \mathrm{mV}$ for the G-quadruplex-loaded (PMAA/PVPON) 13 hydrogel capsules at $\mathrm{pH}=5.5$ and $\mathrm{pH}=7.5$, respectively (Figure 4b). However, capsules loaded with G-quadruplex oligonucleotides increase the magnitude of the negative zeta-potential ( 1.6 -fold at $\mathrm{pH}=5.5$ and 1.5 -fold at $\mathrm{pH}=7.5$ ) at both $\mathrm{pH}$ values compared to the empty capsules at the same concentration of capsules. DNA is negatively charged at neutral pH due to the phosphate ions comprising its backbone and the magnitude of this charge is influenced by salt concentration [79]. Because the solutions contain no added salt, the G-quadruplex oligonucleotides in this work are negatively charged at the $\mathrm{pH}$ ranges shown in Figure $4 \mathrm{~b}$. It is also established that the $\mathrm{p} K_{\mathrm{a}}$ of the individual nucleotide bases are largely overwhelmed by the phosphate $\mathrm{p} K_{\mathrm{a}}(\sim 1)$ when they are assembled into DNA strands and therefore the magnitude of the negative charge on the G-quadruplex oligonucleotides should not shift over the range of $\mathrm{pH}$ values studied [80]. Therefore, our data suggests that the increase in negative zeta-potential value for G-quadruplex-loaded capsules can be attributed to negatively charged G-quadruplex oligonucleotides that can become trapped within the capsule shell after the carbonate template dissolution. 

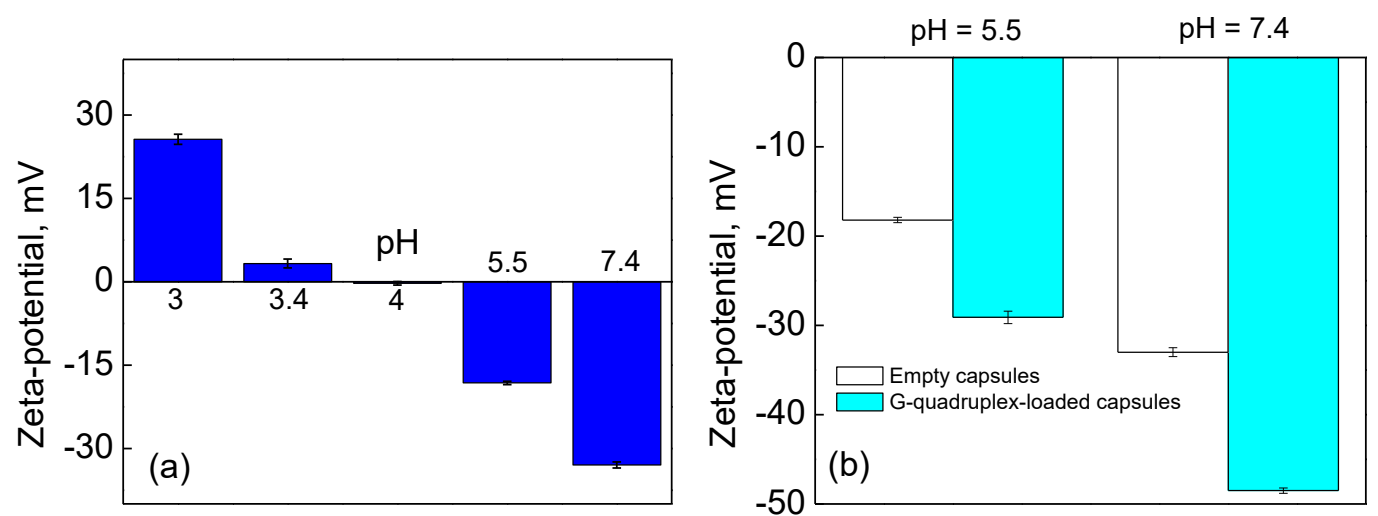

Figure 4. $\mathrm{pH}$-Dependence of zeta-potential values of the (PMAA/PVPON) 13 hydrogel capsules (a) without G-quadruplex DNA and (b) loaded with G-quadruplex DNA. The data is presented as mean $\pm \mathrm{SD}$.

\subsection{Enzymatic Degradation of dsDNA- and G-Quadruplex-Loaded (PMAA/PVPON) ${ }_{n}$ Hydrogel Capsules}

Typical intracellular concentrations of the reducing enzyme GSH have been shown to break the disulfide bond in the cystamine crosslinks as used in our study $[55,56]$. We have also shown that multilayer hydrogel films and particles can degrade completely after incubation with $5 \mathrm{mM}$ GSH in $0.01 \mathrm{M}$ phosphate buffer $(\mathrm{pH}=7.4)$ at $37^{\circ} \mathrm{C}$ [63]. Therefore, we studied the degradability of the (PMAA/PVPON) interpenetrated hydrogel shells in GSH solutions of the same intracellular concentration using turbidimetry. DNA-loaded (PMAA/PVPON) $)_{13}$ capsules were added to $5 \mathrm{mM}$ GSH (0.01 M phosphate) at $\mathrm{pH}=7.4$ and $37^{\circ} \mathrm{C}$, and the turbidity of the solution was monitored fluorometrically at $700 \mathrm{~nm}$ as shown in Figure 5. It is expected that as the disulfide crosslinks between the PMAA chains are reduced to thiols, some polymers resolubilize, causing a decrease in turbidity from the insoluble capsule shell networks [63,64]. Figure 5 shows that, while the untreated (PMAA/PVPON) 13 hydrogel capsules used as the turbidity reference control maintained their turbidity for the 12-h period (Figure 5, squares), the hydrogel capsules loaded with G-quadruplex oligonucleotides exhibited a decrease in solution turbidity of $35 \%$ over $12 \mathrm{~h}$ when treated with $5 \mathrm{mM}$ GSH compared to the untreated capsules (Figure 5, triangles).

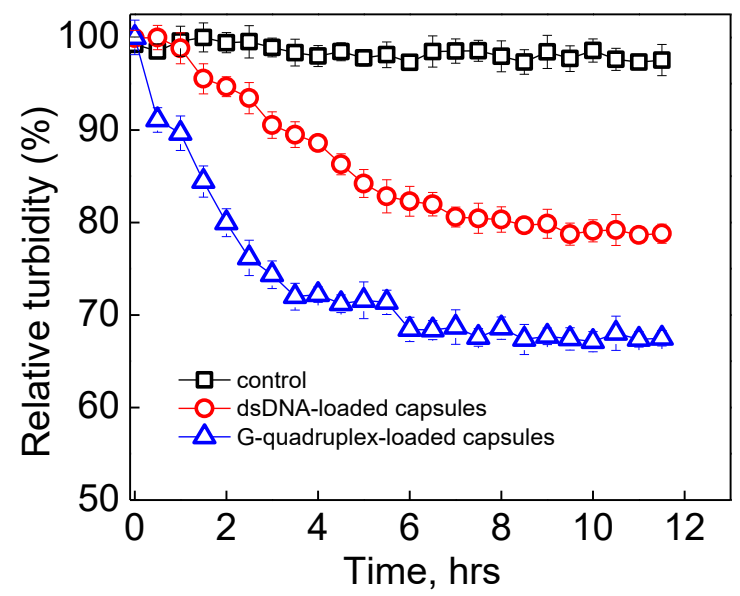

Figure 5. Relative solution turbidity of dsDNA-loaded (red circles), G-quadruplex DNA-loaded (blue triangles) (PMAA/PVPON) 13 hydrogel capsules incubated with $5 \mathrm{mM} \mathrm{GSH} \mathrm{(0.01} \mathrm{M} \mathrm{phosphate,}$ $\mathrm{pH}=7.4$ ) at $37{ }^{\circ} \mathrm{C}$ and non-treated control empty (PMAA/PVPON) 13 (black squares). The data is presented as mean $\pm \mathrm{SD}$. For each marker, five measurements within 1 min of the timepoint were averaged. 
The incomplete decrease in solution turbidity for the G-quadruplex loaded capsules can be attributed to the presence of G-quadruplex oligomers within the capsule shell, which is in agreement with our zeta-potential measurements (Figure 4), as DNA nucleotides can participate in the binding with multilayers and stabilize the capsule shell as shown in previous works $[48,49]$. The DNA molecules initially entrapped into calcium carbonate cores and released into the inner capsule cavity after core dissolution can interact with the PEI priming layer, as well as with single-end reacted amine groups from the cystamine crosslinker, and because of the chain entanglement of PVPON and PMAA, the DNA molecules can additionally stabilize the capsule shell against full hydrogel degradation during crosslink reduction.

To reveal the effect of DNA molecular weight on the shell stabilization, (PMAA/PVPON) 13 hydrogel capsules with double-stranded calf thymus DNA (dsDNA, $450 \mathrm{kDa}$ ) were employed under the same enzymatic conditions and the solution turbidity was measured over time (Figure 5, circles). As shown in Figure 5, the solution turbidity in this case decreased by only $20 \%$ for the dsDNA-loaded capsules, indicating that, compared to the G-quadruplex oligomers, the larger molecular weight dsDNA nucleotides could further increase the stability of the capsule shell against complete enzymatic degradation. We hypothesized that, although the capsules did not completely degrade at the typical concentration of intracellular GSH [81,82], the smaller G-quadruplex DNA could potentially escape the capsules in significant amounts in response to the treatment if the capsule shell was allowed to be thin enough. To test this hypothesis, we prepared 2-fold thinner (PMAA/PVPON) 6 hydrogel capsules loaded with the same concentration of G-quadruplex DNA as the (PMAA/PVPON) 13 capsules to be subjected to GSH treatment as discussed above. After extensive dialysis of the (PMAA/PVPON) 6 capsules after core dissolution to remove calcium ions and any unbound/non-encapsulated DNA, the capsules were subjected to $5 \mathrm{mM} \mathrm{GSH}$ at $\mathrm{pH}=7.4\left(0.01 \mathrm{M}\right.$ phosphate) at $37^{\circ} \mathrm{C}$.

Remarkably, a significant concentration of G-quadruplex DNA of $3 \mu \mathrm{M}$ for the capsules at the same concentration as the experiments discussed above was rapidly (after $30 \mathrm{~min}$ of exposure) released into solution in response to the enzymatic degradation (Figure 6a,c). After stabilizing at $2 \mathrm{~h}$, the total concentration of released DNA was measured to be $2.52 \mu \mathrm{M}$, accounting for $50 \%$ of the DNA loading capacity. The slight decrease in DNA in the capsule supernatant observed over the next $1.5 \mathrm{~h}$ can be attributed to some amounts of the DNA readsorbing on to partially degraded hydrogel shells via interaction with the PEI priming layer. This data demonstrates that enzymatic degradation can offer a viable release pathway for delivery of G-quadruplex oligonucleotides from the (PMAA/PVPON) interpenetrated hydrogel capsules.

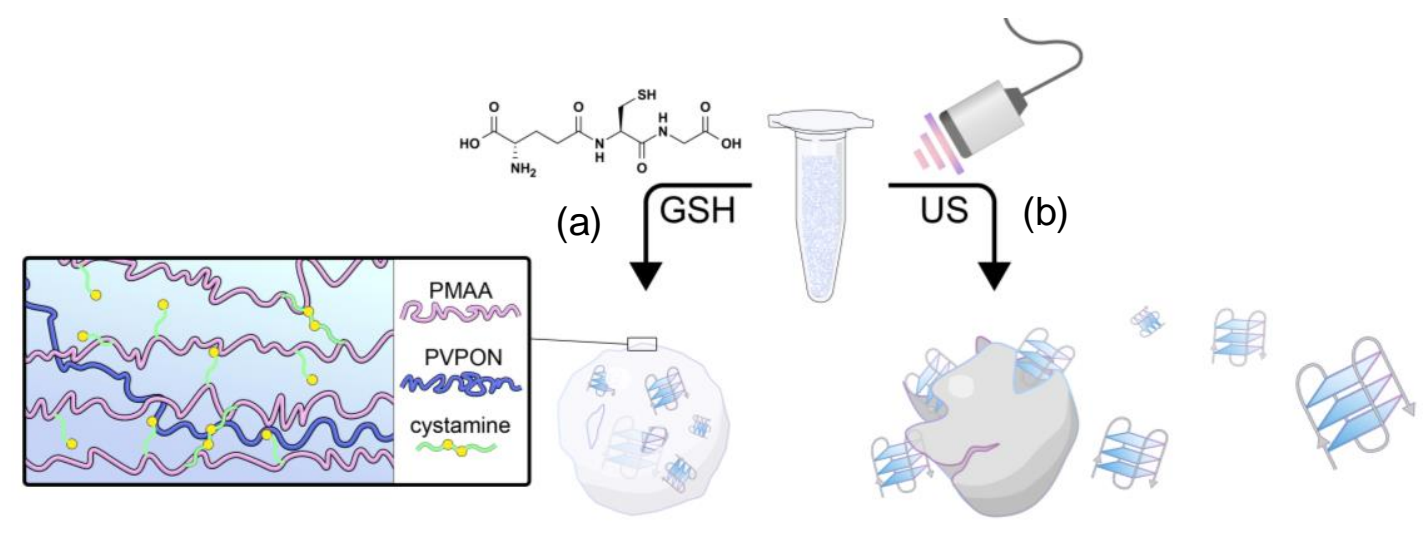

Figure 6. Cont. 

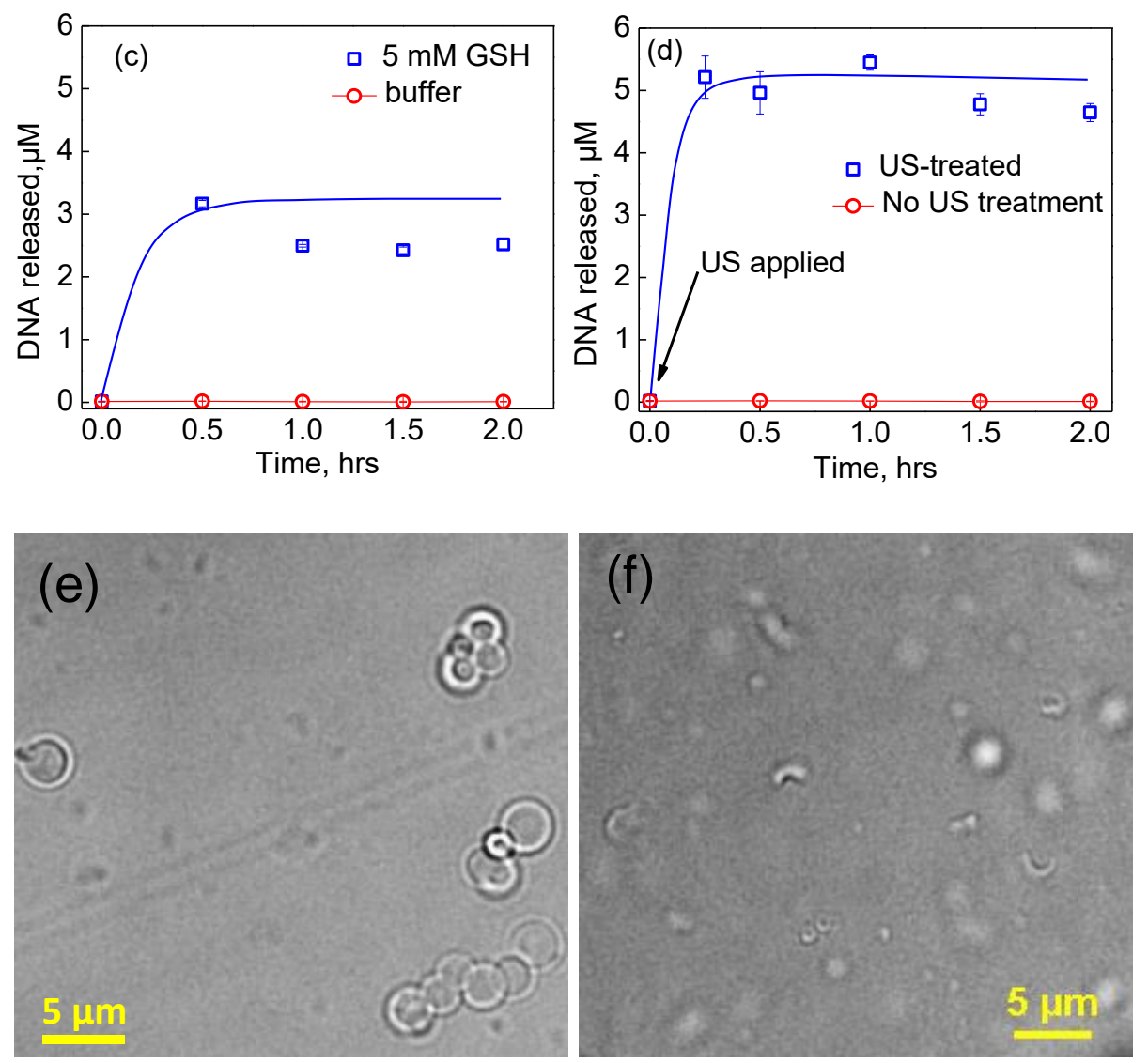

Figure 6. Release of DNA from (PMAA/PVPON) 6 hydrogel capsules via (a) GSH-treatment and (b) US irradiation. Capsules treated (c) with $5 \mathrm{mM} \mathrm{GSH}$ at $37{ }^{\circ} \mathrm{C}$ and (d) with US, were pelleted via centrifugation and the supernatant was removed for quantification via UV-Vis absorbance at $260 \mathrm{~nm}$. For each marker, three aliquots were taken for measurement and averaged. Optical images of (PMAA/PVPON) 6 hydrogel capsules (e) before and (f) after US irradiation (14 W/ $\mathrm{cm}^{2}$ for $60 \mathrm{~s}$ in 20-s bursts).

\subsection{Ultrasound (US)-Triggered Release of G-Quadruplex DNA from (PMAA/PVPON) ${ }_{n}$ Hydrogel Capsules}

Because of the incomplete release of oligonucleotides from the G-quadruplex DNA-loaded (PMAA/PVPON) hydrogel capsules due to the stabilization of the capsule shell via its interactions with the DNA molecules, we studied the ability of the (PMAA/PVPON) hydrogel capsules to release G-quadruplex DNA upon US irradiation (Figure 6b). G-quadruplex DNA-loaded (PMAA/PVPON) 6 were exposed to $22 \mathrm{kHz}$ US at $14 \mathrm{~W} / \mathrm{cm}^{2}$ for $60 \mathrm{~s}$ in 20-s bursts. After the exposure, the supernatant of each capsule solution was monitored using UV-Vis spectroscopy to calculate the concentration of G-quadruplex DNA released per capsule in the sample, as optical microscopy revealed that the US treatment had quantitatively destroyed the capsules (Figure 6e,f). This result is in agreement with the observation we made in a previous study that the mechanical force of this $22 \mathrm{kHz}$ ultrasound irradiation is sufficient to completely destroy our multilayer microcapsules [65]. For the (PMAA/PVPON) 6 capsules, we found that approximately 37 attomoles of G-quadruplex oligonucleotides were released per capsule ( $4.95 \mu \mathrm{M}$ at $1 \mathrm{~mL}$ of $1.6 \times 10^{8}$ capsules $/ \mathrm{mL}$ ) (Figure $6 \mathrm{c}$ ). As the US irradiation completely destroyed all capsules in solution, rendering them into small fragments, the released DNA that was not readsorbed onto the polymeric complex fragments was taken as the effective loading capacity, i.e., the highest amount of DNA that could be released from the capsules. This value was used to calculate the \% release of DNA resulting from the GSH treatment as discussed above. Previously, double- and single-stranded DNA was encapsulated within PMAA hydrogel capsules prepared using porous silica spheres as the core template [83]. In that study, it was found that the upper limit to the number of 
20-mer ssDNA strands that could be adsorbed to the surface of the silica template, and thus become encapsulated, approached 10,000 chains per capsule. In contrast, we show a significant increase in the number of 24-mer G-quadruplex oligonucleotide chains that can be loaded per capsule, representing about a 2000-fold increase in encapsulated DNA by utilizing the entire volume of the core during DNA co-precipitation.

Importantly, the sonoporation effect of US irradiation is accompanied by microbubble cavitation that can cause local heating and high mechanical pressure [33]. In this regard, it is important that the US pressure used to release encapsulated nucleotides does not have harmful effects on the structure of the DNA. Especially in the case of G-quadruplex forming sequences, where the secondary structure of the DNA plays a crucial role in its function [13], ensuring that the stacked tetrad conformation is intact after encapsulation and release is essential in promoting the efficacy of the delivery system as a therapeutic strategy. Therefore, to determine if the encapsulation strategy and US-triggered release used in this work was suitable for G-quadruplex delivery, we first studied the effect of coprecipitation and core dissolution on the structure of the G-quadruplex oligonucleotides using circular dichroism (CD) spectroscopy (Figure 7a).
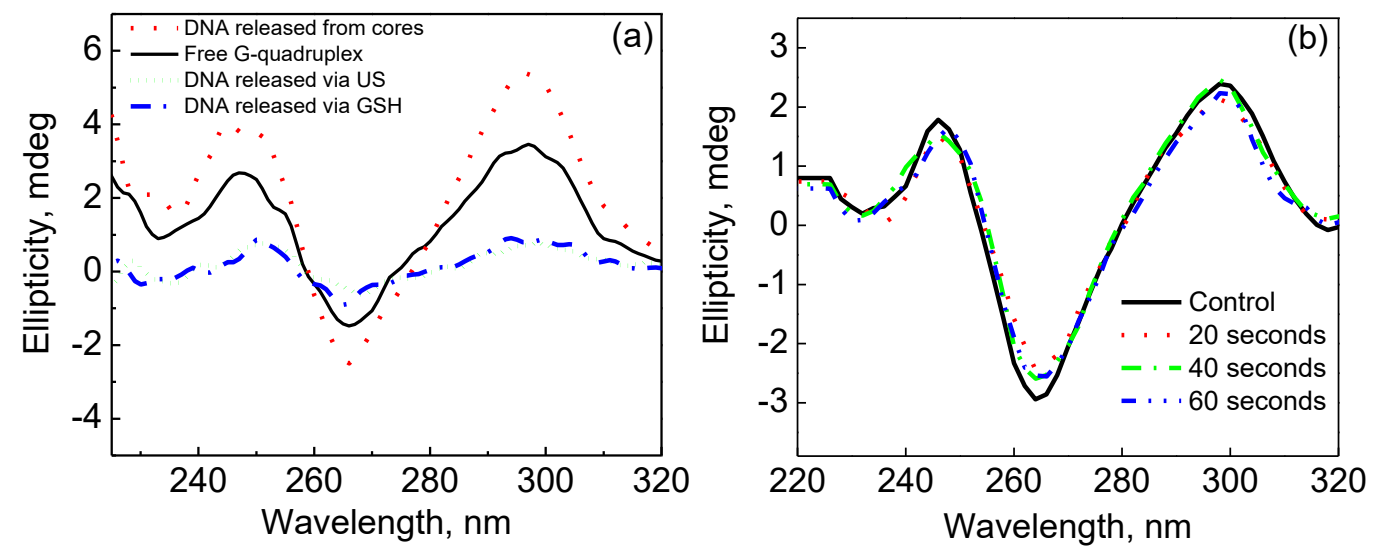

Figure 7. CD spectra of free G-quadruplex oligonucleotides (solid black) after encapsulation and release from the $\mathrm{CaCO}_{3}$ cores via dissolution in EDTA (dot red) or after release from the (PMAA/PVPON) 13 capsules via degradation by GSH (dash dot blue) or $22 \mathrm{kHz}$ ultrasound ( $55 \mathrm{~W} / \mathrm{cm}^{2}$ for $20 \mathrm{~s}$ ) (short dot green). G-quadruplex oligonucleotides (solid black) were exposed to $22 \mathrm{kHz}$ ultrasound $\left(55 \mathrm{~W} / \mathrm{cm}^{2}\right.$ ) for various times and measured for retention of secondary structure.

A solution of free G-quadruplex oligonucleotide was used as a positive control and the characteristic peaks and trough $(245,295$, and $265 \mathrm{~nm}$, respectively) for a G-quadruplex basket structure [84] can be seen in Figure 7a (solid black line). The spectrum in Figure 7a corresponding to coprecipitated and released G-quadruplex (Figure 7a, red dot line) shows the same characteristic peaks and trough as the free control (Figure 7a, solid black line), which indicates that trapping the nucleotide within the crystalline $\mathrm{CaCO}_{3}$ network and subsequently releasing it by dissolving the precipitated particles in EDTA solution did not alter the secondary structure of the G-quadruplex DNA sequence. Similar results were also found for G-quadruplex oligonucleotides released from (PMAA/PVPON) capsules via US irradiation (Figure 7a, short dot green line). In addition, the CD spectrum of G-quadruplex DNA released from capsules via GSH-triggered crosslink reduction has the same features as the former ones (Figure 7a, dash dot blue line).

All samples of released DNA were found to retain their secondary structure as indicated by the characteristic peaks that match that of the free G-quadruplex DNA control (Figure 7a). To demonstrate the robust nature of the G-quadruplex stacked tetrads, solutions of free G-quadruplex oligonucleotides were exposed to US of $55 \mathrm{~W} / \mathrm{cm}^{2}$ for 20,40, or $60 \mathrm{~s}$ and were monitored using circular dichroism to detect any changes to the secondary structure of the G-quadruplex (Figure $7 \mathrm{~b}$ ). After US exposure, the characteristic basket conformation peaks for a G-quadruplex stack were observed for all solutions 
(Figure 7b). The lack of change to the secondary structure for US-exposed nucleotides indicates that the G-quadruplex is stable enough to undergo US treatment totaling at least $55 \mathrm{~W} / \mathrm{cm}^{2}$ power intensity (almost three times the power applied in our release studies for PMAA/PVPON hydrogel capsules) for up to $60 \mathrm{~s}$ and remain in its folded state. This is in good agreement with previous reports on the effects of sonication on G-quadruplex structure [84]. Our data shows that our encapsulation strategy, enzymatic degradation approach, and, most importantly, our US-triggered release of G-quadruplex from the (PMAA/PVPON) $n$ hydrogel capsules represents a viable pathway to controlled delivery of the nucleotide that stands up against any potentially harmful effects of the delivery method.

\subsection{Encapsulation and US-Triggered Release of dsDNA from (PMAA/PVPON) ${ }_{13}$ Capsules}

To explore the versatility of the (PMAA/PVPON $)_{n}$ interpenetrated hydrogel capsules and demonstrate the potential of US-triggered release from the hydrogel capsules, we also explored this system for encapsulation and release of dsDNA with a molecular weight 60 times larger than that of the G-quadruplex oligonucleotides. As summarized in Figure 1, dsDNA was coprecipitated within $\mathrm{CaCO}_{3}$ particles followed by assembly of 13 bilayers of PMAA/PVPON, which represents the system with the highest resistance to mechanical pressure among those that we have used in the current study. Ethidium bromide (EtBr), a well-known DNA intercalator [85], was used as a fluorescent label in the release studies. We examined the ability of our capsules to release dsDNA upon US exposure as described earlier for the release of G-quadruplex oligonucleotides. Solutions of dsDNA-loaded (PMAA/PVPON) 13 hydrogel capsules were exposed to US at $55 \mathrm{~W} / \mathrm{cm}^{2}$ power intensity for $20 \mathrm{~s}$ and the supernatant was examined for the presence of dsDNA released from the capsules via fluorescence measurements. As the molar extinction coefficient of dsDNA is much lower than that of the G-quadruplex oligomers, $\left(6600 \mathrm{M}^{-1} \cdot \mathrm{cm}^{-1}\right.$ versus $228,500 \mathrm{M}^{-1} \cdot \mathrm{cm}^{-1}$, respectively) [86], UV-Vis spectroscopy was not useful in quantifying the released DNA. To solve this, the binding of $\mathrm{EtBr}$ to the dsDNA and subsequent linear relationship [85] in fluorescence spectroscopy was utilized as a way to monitor the amount of dsDNA present in the supernatant (Figure 8a). We found that a suspension of $1.6 \times 10^{8}$ capsules $/ \mathrm{mL}$, i.e., the same concentration of capsules as used in the G-quadruplex release studies, resulted in an US-triggered release of dsDNA totaling $180 \mu \mathrm{M}$ (Figure $8 \mathrm{~b}$ ). The release data for dsDNA shows that the (PMAA/PVPON) interpenetrated hydrogel capsules may serve as a generalizable encapsulation and delivery vehicle for nucleotides of a wide range of molecular weights and functions.
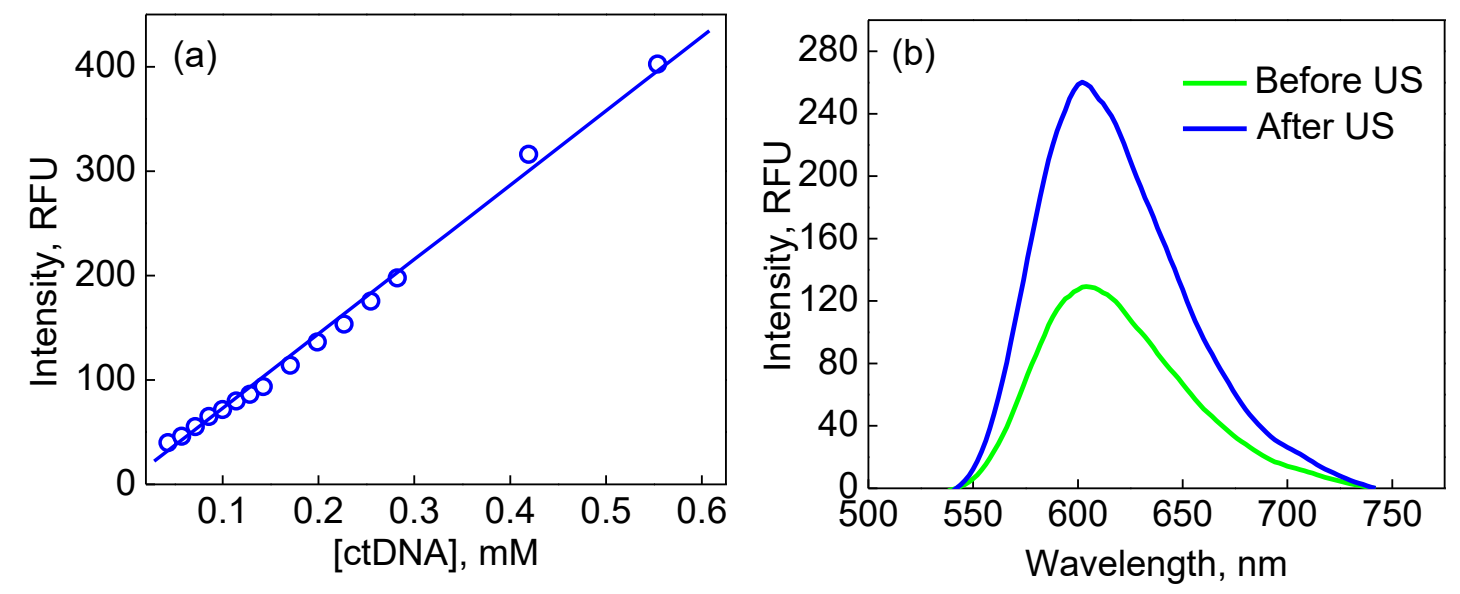

Figure 8. (a) dependence of fluorescence of dsDNA intercalated with EtBr on dsDNA concentration; (b) release of dsDNA from (PMAA/PVPON) 13 capsules after US-treatment with $22 \mathrm{kHz}$ US $\left(55 \mathrm{~W} / \mathrm{cm}^{2}\right.$ for $20 \mathrm{~s}$ ) as quantified with fluorescence microscopy. 


\section{Conclusions}

New and promising roles for nucleic acid therapeutics have been emerging in recent studies. However, challenges with delivery and efficiency have limited their prospects for translation. We address the need for improved delivery vehicles of nucleic acids in this work through the development of multilayer capsules made of interpenetrated hydrogel of (PMAA/PVPON) that can be used for the encapsulation and release of various DNA structures including G-quadruplex and double-stranded helices. We show that (PMAA/PVPON) $)_{n}$ capsules loaded with either G-quadruplex or dsDNA have a higher effective loading capacity compared to previous studies, decreasing the number of capsules required per dose. In addition, we show that these capsules are responsive toward both enzymatic degradation by intracellular concentration of the reducing enzyme GSH and US exposure, allowing for precisely controlled delivery of the DNA cargo. These hydrogel capsules represent a significant advancement in the potential of microparticle drug delivery agents that enable the most desirable properties of gene-based therapeutics and may help bridge the gap toward realizing the next generation of life saving therapeutic strategies for disease treatment.

Author Contributions: A.A. and B.T. contributed equally to writing, experimental design, and data analysis. V.K. and J.C. contributed to experimental design, instrumentation, writing, and conceptualization. R.C. and J.G. contributed to methods optimization and data analysis. N.G. contributed to data analysis and instrumentation. D.G. and E.K. contributed to writing, reviewing, experimental design, instrumentation, and conceptualization.

Funding: This work was supported by NSF DMR Career Award No. 1350370.

Acknowledgments: The UAB SEM and High Resolution Imaging Facility (Confocal Laser Scanning Microscopy Imaging) is acknowledged.

Conflicts of Interest: The authors declare no conflict of interest.

\section{References}

1. Breslauer, K.; Frank, R.; Blöcker, H.; Marky, L. Predicting DNA Duplex Stability from the Base Sequence. Proc. Natl. Acad. Sci. USA 1986, 83, 3746-3750. [CrossRef] [PubMed]

2. Rich, A.; Zhang, S. Z-DNA: The long road to biological function. Nat. Rev. Genet. 2003, 4, 566. [CrossRef] [PubMed]

3. Lu, C.-H.; Willner, B.; Willner, I. DNA nanotechnology: From sensing and DNA machines to drug-delivery systems. ACS Nano 2013, 7, 8320-8332. [CrossRef] [PubMed]

4. Ivanov, A.P.; Actis, P.; Jönsson, P.; Klenerman, D.; Korchev, Y.; Edel, J.B. On-demand delivery of single DNA molecules using nanopipets. ACS Nano 2015, 9, 3587-3595. [CrossRef] [PubMed]

5. Nguyen, D.N.; Green, J.J.; Chan, J.M.; Langer, R.; Anderson, D.G. Polymeric materials for gene delivery and DNA vaccination. Adv. Mater. 2008, 21, 847-867. [CrossRef] [PubMed]

6. Bauhuber, S.; Hozsa, C.; Breunig, M.; Göpferich, A. Delivery of nucleic acids via disulfide-based carrier systems. Adv. Mater. 2009, 21, 3286-3306. [CrossRef] [PubMed]

7. Mastorakos, P.; da Silva, A.L.; Chisholm, J.; Song, E.; Choi, W.K.; Boyle, M.P.; Morales, M.M.; Hanes, J.; Suk, J.S. Highly compacted biodegradable DNA nanoparticles capable of overcoming the mucus barrier for inhaled lung gene therapy. Proc. Natl. Acad. Sci. USA 2015, 112, 8720. [CrossRef] [PubMed]

8. Alton, E.W.F.W.; Armstrong, D.K.; Ashby, D.; Bayfield, K.J.; Bilton, D.; Bloomfield, E.V.; Boyd, A.C.; Brand, J.; Buchan, R.; Calcedo, R.; et al. Repeated nebulisation of non-viral CFTR gene therapy in patients with cystic fibrosis: A randomised, double-blind, placebo-controlled, phase 2b trial. Lancet Respir. Med. 2015, 3, 684-691. [CrossRef]

9. Han, H.; Hurley, L.H. G-quadruplex DNA: A potential target for anti-cancer drug design. Trends Pharmacol. Sci. 2000, 21, 136-142. [CrossRef]

10. Biffi, G.; Tannahill, D.; McCafferty, J.; Balasubramanian, S. Quantitative visualization of DNA g-quadruplex structures in human cells. Nat. Chem. 2013, 5, 182-186. [CrossRef]

11. Maizels, N.; Gray, L.T. The g4 genome. PLOS Genet. 2013, 9, e1003468. [CrossRef]

12. Bochman, M.L.; Paeschke, K.; Zakian, V.A. DNA secondary structures: Stability and function of g-quadruplex structures. Nat. Rev. Genet. 2012, 13, 770. [CrossRef] 
13. Tucker, B.A.; Hudson, J.S.; Ding, L.; Lewis, E.; Sheardy, R.D.; Kharlampieva, E.; Graves, D. Stability of the na+ form of the human telomeric g-quadruplex: Role of adenines in stabilizing g-quadruplex structure. ACS Omega 2018, 3, 844-855. [CrossRef] [PubMed]

14. Rhodes, D.; Lipps, H.J. G-quadruplexes and their regulatory roles in biology. Nucleic Acids Res. 2015, 43, 8627-8637. [CrossRef] [PubMed]

15. Macaya, R.F.; Schultze, P.; Smith, F.W.; Roe, J.A.; Feigon, J. Thrombin-binding DNA aptamer forms a unimolecular quadruplex structure in solution. Proc. Natl. Acad. Sci. USA 1993, 90, 3745. [CrossRef]

16. Tombelli, S.; Minunni, M.; Mascini, M. Analytical applications of aptamers. Biosens. Bioelectron. 2005, 20, 2424-2434. [CrossRef] [PubMed]

17. Düchler, M. G-quadruplexes: Targets and tools in anticancer drug design. J. Drug Target. 2012, 20, 389-400. [CrossRef]

18. Graziella, C.-R.; Nadia, Z.; Marco, F. Emerging role of g-quadruplex DNA as target in anticancer therapy. Curr. Pharm. Des. 2016, 22, 6612-6624. [CrossRef]

19. Buket, O.; Clement, L.I.N.; DanZhou, Y. DNA g-quadruplex and its potential as anticancer drug target. Sci. China Chem. 2014, 57, 1605-1614. [CrossRef]

20. Herweijer, H.; Wolff, J.A. Progress and prospects: Naked DNA gene transfer and therapy. Gene Ther. 2003, 10, 453. [CrossRef]

21. Wang, W.; Balk, M.; Deng, Z.; Wischke, C.; Gossen, M.; Behl, M.; Ma, N.; Lendlein, A. Engineering biodegradable micelles of polyethylenimine-based amphiphilic block copolymers for efficient DNA and sirna delivery. J. Control. Release 2016, 242, 71-79. [CrossRef] [PubMed]

22. Beavers Kelsey, R.; Werfel Thomas, A.; Shen, T.; Kavanaugh Taylor, E.; Kilchrist Kameron, V.; Mares Jeremy, W.; Fain Joshua, S.; Wiese Carrie, B.; Vickers Kasey, C.; Weiss Sharon, M.; et al. Porous silicon and polymer nanocomposites for delivery of peptide nucleic acids as anti-microrna therapies. Adv. Mater. 2016, 28, 7984-7992. [CrossRef] [PubMed]

23. Lambricht, L.; Lopes, A.; Kos, S.; Sersa, G.; Préat, V.; Vandermeulen, G. Clinical potential of electroporation for gene therapy and DNA vaccine delivery. Expert Opin. Drug Deliv. 2016, 13, 295-310. [CrossRef] [PubMed]

24. Molla Mijanur, R.; Levkin Pavel, A. Combinatorial approach to nanoarchitectonics for nonviral delivery of nucleic acids. Adv. Mater. 2015, 28, 1159-1175. [CrossRef] [PubMed]

25. Lehto, T.; Ezzat, K.; Wood, M.J.A.; El Andaloussi, S. Peptides for nucleic acid delivery. Adv. Drug Deliv. Rev. 2016, 106, 172-182. [CrossRef]

26. Luo, D.; Saltzman, W.M. Synthetic DNA delivery systems. Nat. Biotechnol. 2000, 18, 33. [CrossRef] [PubMed]

27. Hackett, P.B.; Largaespada, D.A.; Switzer, K.C.; Cooper, L.J.N. Evaluating risks of insertional mutagenesis by DNA transposons in gene therapy. Transl. Res. J. Lab. Clin. Med. 2013, 161, 265-283. [CrossRef]

28. Hardee, C.L.; Arévalo-Soliz, L.M.; Hornstein, B.D.; Zechiedrich, L. Advances in non-viral DNA vectors for gene therapy. Genes 2017, 8, 65. [CrossRef]

29. Keeney, M.; Ong, S.-G.; Padilla, A.; Yao, Z.; Goodman, S.; Wu, J.C.; Yang, F. Development of poly( $\beta$-amino ester)-based biodegradable nanoparticles for nonviral delivery of minicircle DNA. ACS Nano 2013, 7, 7241-7250. [CrossRef]

30. Richardson Joseph, J.; Choy Mei, Y.; Guo, J.; Liang, K.; Alt, K.; Ping, Y.; Cui, J.; Law Lok, S.; Hagemeyer Christoph, E.; Caruso, F. Polymer capsules for plaque-targeted in vivo delivery. Adv. Mater. 2016, 28, 7703-7707. [CrossRef]

31. Phillips, L.C.; Klibanov, A.L.; Wamhoff, B.R.; Hossack, J.A. Targeted gene transfection from microbubbles into vascular smooth muscle cells using focused, ultrasound-mediated delivery. Ultrasound Med. Boil. 2010, 36, 1470-1480. [CrossRef] [PubMed]

32. Xie, A.; Belcik, T.; Qi, Y.; Morgan, T.K.; Champaneri, S.A.; Taylor, S.; Davidson, B.P.; Zhao, Y.; Klibanov, A.L.; Kuliszewski, M.A.; et al. Ultrasound-mediated vascular gene transfection by cavitation of endothelial-targeted cationic microbubbles. JACC Cardiovasc. Imaging 2012, 5, 1253-1262. [CrossRef] [PubMed]

33. Fan, Z.; Kumon, R.E.; Deng, C.X. Mechanisms of microbubble-facilitated sonoporation for drug and gene delivery. Therap. Deliv. 2014, 5, 467-486. [CrossRef] [PubMed]

34. Kozlovskaya, V.; Kharlampieva, E.; Erel, I.; Sukhishvili, S.A. Multilayer-derived, ultrathin, stimuli-responsive hydrogels. Soft Matter 2009, 5, 4077-4087. [CrossRef] 
35. Kharlampieva, E.; Kozlovskaya, V.; Sukhishvili, S.A. Layer-by-layer hydrogen-bonded polymer films: From fundamentals to applications. Adv. Mater. 2009, 21, 3053-3065. [CrossRef]

36. Lvov, Y.; Decher, G.; Sukhorukov, G. Assembly of thin films by means of successive deposition of alternate layers of DNA and poly(allylamine). Macromolecules 1993, 26, 5396-5399. [CrossRef]

37. Lvov, Y.M.; Lu, Z.; Schenkman, J.B.; Zu, X.; Rusling, J.F. Direct electrochemistry of myoglobin and cytochrome p450cam in alternate layer-by-layer films with DNA and other polyions. J. Am. Chem. Soc. 1998, 120, 4073-4080. [CrossRef]

38. Decher, G.; Lehr, B.; Lowack, K.; Lvov, Y.; Schmitt, J. New nanocomposite films for biosensors: Layer-by-layer adsorbed films of polyelectrolytes, proteins or DNA. Biosens. Bioelectron. 1994, 9, 677-684. [CrossRef]

39. Lynn, D.M. Polyelectrolyte Multilayer Coatings for the Release and Transfer of Plasmid DNA. In Layer-by-Layer Films for Biomedical Applications; Picart, C., Caruso, F., Voegel, J., Eds.; Wiley: Hoboken, NJ, USA, 2015. [CrossRef]

40. Appadoo, V.; Carter, M.C.D.; Lynn, D.M. Controlling the surface-mediated release of DNA using 'mixed multilayers'. Bioeng. Transl. Med. 2016, 1, 181-192. [CrossRef]

41. Yu, Y.; Si, Y.; Bechler, S.L.; Liu, B.; Lynn, D.M. Polymer multilayers that promote the rapid release and contact transfer of DNA. Biomacromolecules 2015, 16, 2998-3007. [CrossRef]

42. Castleberry, S.A.; Golberg, A.; Sharkh, M.A.; Khan, S.; Almquist, B.D.; Austen, W.G.; Yarmush, M.L.; Hammond, P.T. Nanolayered sirna delivery platforms for local silencing of CTGF reduce cutaneous scar contraction in third-degree burns. Biomaterials 2016, 95, 22-34. [CrossRef] [PubMed]

43. Roh, Y.H.; Lee, J.B.; Shopsowitz, K.E.; Dreaden, E.C.; Morton, S.W.; Poon, Z.; Hong, J.; Yamin, I.; Bonner, D.K.; Hammond, P.T. Layer-by-layer assembled antisense DNA microsponge particles for efficient delivery of cancer therapeutics. ACS Nano 2014, 8, 9767-9780. [CrossRef] [PubMed]

44. de Villiers, M.M.; Lvov, Y.M. Layer-by-layer self-assembled nanoshells for drug delivery. Adv. Drug Deliv. Rev. 2011, 63, 699-700. [CrossRef] [PubMed]

45. Kozlovskaya, V.; Higgins, W.; Chen, J.; Kharlampieva, E. Shape switching of hollow layer-by-layer hydrogel microcontainers. Chem. Commun. 2011, 47, 8352-8354. [CrossRef]

46. Chen, J.; Kozlovskaya, V.; Goins, A.; Campos-Gomez, J.; Saeed, M.; Kharlampieva, E. Biocompatible shaped particles from dried multilayer polymer capsules. Biomacromolecules 2013, 14, 3830-3841. [CrossRef]

47. Vergaro, V.; Scarlino, F.; Bellomo, C.; Rinaldi, R.; Vergara, D.; Maffia, M.; Baldassarre, F.; Giannelli, G.; Zhang, X.; Lvov, Y.M.; et al. Drug-loaded polyelectrolyte microcapsules for sustained targeting of cancer cells. Adv. Drug Deliv. Rev. 2011, 63, 847-864. [CrossRef]

48. Cavalieri, F.; Postma, A.; Lee, L.; Caruso, F. Assembly and functionalization of DNA-polymer microcapsules. ACS Nano 2009, 3, 234-240. [CrossRef]

49. Kakade, S.; Manickam, D.S.; Handa, H.; Mao, G.; Oupický, D. Transfection activity of layer-by-layer plasmid DNA/poly(ethylenimine) films deposited on plga microparticles. Int. J. Pharm. 2009, 365, 44-52. [CrossRef]

50. Elsner, N.; Kozlovskaya, V.; Sukhishvili, S.A.; Fery, A. pH-triggered softening of crosslinked hydrogen-bonded capsules. Soft Matter 2006, 2, 966-972. [CrossRef]

51. Kozlovskaya, V.; Wang, Y.; Higgins, W.; Chen, J.; Chen, Y.; Kharlampieva, E. pH-triggered shape response of cubical ultrathin hydrogel capsules. Soft Matter 2012, 8, 9828-9839. [CrossRef]

52. De Geest, B.G.; Skirtach, A.G.; Mamedov, A.A.; Antipov, A.A.; Kotov, N.A.; De Smedt, S.C.; Sukhorukov, G.B. Ultrasound-triggered release from multilayered capsules. Small 2007, 3, 804-808. [CrossRef] [PubMed]

53. Kozlovskaya, V.; Shamaev, A.; Sukhishvili, S.A. Tuning swelling ph and permeability of hydrogel multilayer capsules. Soft Matter 2008, 4, 1499-1507. [CrossRef]

54. Shchukin, D.G.; Patel, A.A.; Sukhorukov, G.B.; Lvov, Y.M. Nanoassembly of biodegradable microcapsules for DNA encasing. J. Am. Chem. Soc. 2004, 126, 3374-3375. [CrossRef] [PubMed]

55. Zelikin, A.N.; Li, Q.; Caruso, F. Degradable polyelectrolyte capsules filled with oligonucleotide sequences. Angew. Chem. Int. Ed. 2006, 45, 7743-7745. [CrossRef] [PubMed]

56. Ng, S.L.; Such, G.K.; Johnston, A.P.R.; Antequera-García, G.; Caruso, F. Controlled release of DNA from poly(vinylpyrrolidone) capsules using cleavable linkers. Biomaterials 2011, 32, 6277-6284. [CrossRef]

57. Borodina, T.; Markvicheva, E.; Kunizhev, S.; Möhwald, H.; Sukhorukov Gleb, B.; Kreft, O. Controlled release of DNA from self-degrading microcapsules. Macromol. Rapid Commun. 2007, 28, 1894-1899. [CrossRef]

58. Li, L.; Puhl, S.; Meinel, L.; Germershaus, O. Silk fibroin layer-by-layer microcapsules for localized gene delivery. Biomaterials 2014, 35, 7929-7939. [CrossRef] 
59. Deng, C.X.; Sieling, F.; Pan, H.; Cui, J. Ultrasound-induced cell membrane porosity. Ultrasound Med. Biol. 2004, 30, 519-526. [CrossRef]

60. Pan, H.; Zhou, Y.; Izadnegahdar, O.; Cui, J.; Deng, C.X. Study of sonoporation dynamics affected by ultrasound duty cycle. Ultrasound Med. Biol. 2005, 31, 849-856. [CrossRef]

61. Zhou, Y.; Kumon, R.E.; Cui, J.; Deng, C.X. The size of sonoporation pores on the cell membrane. Ultrasound Med. Biol. 2009, 35, 1756-1760. [CrossRef]

62. Zarnitsyn, V.; Rostad, C.A.; Prausnitz, M.R. Modeling transmembrane transport through cell membrane wounds created by acoustic cavitation. Biophys. J. 2008, 95, 4124-4138. [CrossRef] [PubMed]

63. Xue, B.; Kozlovskaya, V.; Liu, F.; Chen, J.; Williams, J.F.; Campos-Gomez, J.; Saeed, M.; Kharlampieva, E. Intracellular degradable hydrogel cubes and spheres for anti-cancer drug delivery. ACS Appl. Mater. Interfaces 2015, 7, 13633-13644. [CrossRef] [PubMed]

64. Xue, B.; Wang, W.; Qin, J.-J.; Nijampatnam, B.; Murugesan, S.; Kozlovskaya, V.; Zhang, R.; Velu, S.E.; Kharlampieva, E. Highly efficient delivery of potent anticancer iminoquinone derivative by multilayer hydrogel cubes. Acta Biomater. 2017, 58, 386-398. [CrossRef] [PubMed]

65. Chen, J.; Ratnayaka, S.; Alford, A.; Kozlovskaya, V.; Liu, F.; Xue, B.; Hoyt, K.; Kharlampieva, E. Theranostic multilayer capsules for ultrasound imaging and guided drug delivery. ACS Nano 2017, 11, 3135-3146. [CrossRef] [PubMed]

66. Alford, A.; Rich, M.; Kozlovskaya, V.; Chen, J.; Sherwood, J.; Bolding, M.; Warram, J.; Bao, Y.; Kharlampieva, E. Ultrasound-triggered delivery of anticancer therapeutics from mri-visible multilayer microcapsules. Adv. Ther. 2018, 1, 1800051. [CrossRef]

67. Hynynen, K. Ultrasound for drug and gene delivery to the brain. Adv. Drug Deliv. Rev. 2008, 60, 1209-1217. [CrossRef] [PubMed]

68. Lawrie, A.; Brisken, A.F.; Francis, S.E.; Cumberland, D.C.; Crossman, D.C.; Newman, C.M. Microbubble-enhanced ultrasound for vascular gene delivery. Gene Ther. 2000, 7, 2023. [CrossRef]

69. Melodelima, D.; Chapelon, J.Y.; Theillère, Y.; Cathignol, D. Combination of thermal and cavitation effects to generate deep lesions with an endocavitary applicator using a plane transducer: Ex vivo studies. Ultrasound Med. Biol. 2004, 30, 103-111. [CrossRef]

70. Huynh, E.; Leung, B.Y.C.; Helfield, B.L.; Shakiba, M.; Gandier, J.-A.; Jin, C.S.; Master, E.R.; Wilson, B.C.; Goertz, D.E.; Zheng, G. In situ conversion of porphyrin microbubbles to nanoparticles for multimodality imaging. Nat. Nanotechnol. 2015, 10, 325. [CrossRef]

71. Kozlovskaya, V.; Chen, J.; Zavgorodnya, O.; Hasan, M.B.; Kharlampieva, E. Multilayer hydrogel capsules of interpenetrated network for encapsulation of small molecules. Langmuir 2018, 34, 11832-11842. [CrossRef]

72. Kozlovskaya, V.; Xue, B.; Lei, W.; Padgett, L.E.; Tse, H.M.; Kharlampieva, E. Hydrogen-bonded multilayers of tannic acid as mediators of t-cell immunity. Adv. Healthcare Mater. 2015, 4, 686-694. [CrossRef] [PubMed]

73. Kozlovskaya, V.; Alexander, J.F.; Wang, Y.; Kuncewicz, T.; Liu, X.; Godin, B.; Kharlampieva, E. Internalization of red blood cell-mimicking hydrogel capsules with ph-triggered shape responses. ACS Nano 2014, 8 , 5725-5737. [CrossRef] [PubMed]

74. Kozlovskaya, V.; Chen, J.; Tedjo, C.; Liang, X.; Campos-Gomez, J.; Oh, J.; Saeed, M.; Lungu, C.T.; Kharlampieva, E. Ph-responsive hydrogel cubes for release of doxorubicin in cancer cells. J. Mater. Chem. B 2014, 2, 2494-2507. [CrossRef]

75. Liang, X.; Kozlovskaya, V.; Chen, Y.; Zavgorodnya, O.; Kharlampieva, E. Thermosensitive multilayer hydrogels of poly(N-vinylcaprolactam) as nanothin films and shaped capsules. Chem. Mater. 2012, 24, 3707-3719. [CrossRef] [PubMed]

76. Kozlovskaya, V.; Zavgorodnya, O.; Ankner, J.F.; Kharlampieva, E. Controlling internal organization of multilayer poly(methacrylic acid) hydrogels with polymer molecular weight. Macromolecules 2015, 48, 8585-8593. [CrossRef]

77. Kozlovskaya, V.; Zavgorodnya, O.; Wang, Y.; Ankner, J.F.; Kharlampieva, E. Tailoring architecture of nanothin hydrogels: Effect of layering on pH-triggered swelling. ACS Macro Lett. 2013, 2, 226-229. [CrossRef]

78. Taboury, J.; Liquier, J.; Taillandier, E. Characterization of DNA structures by infrared spectroscopy: Double helical forms of poly $(\mathrm{dG}-\mathrm{dC}) \cdot \operatorname{poly}(\mathrm{dG}-\mathrm{dC})$, poly $(\mathrm{dd} 8 \mathrm{G}-\mathrm{dC}) \cdot$ poly $(\mathrm{dd} 8 \mathrm{G}-\mathrm{dC})$, and poly $(\mathrm{dG}-\mathrm{dm} 5 \mathrm{C})$. poly(dG-dm5C). Can. J. Chem. 2011, 63, 1904-1909. [CrossRef]

79. Bloomfield Victor, A. DNA condensation by multivalent cations. Biopolymers 1997, 44, 269-282. [CrossRef] 
80. Verdolino, V.; Cammi, R.; Munk, B.H.; Schlegel, H.B. Calculation of pKa values of nucleobases and the guanine oxidation products guanidinohydantoin and spiroiminodihydantoin using density functional theory and a polarizable continuum model. J. Phys. Chem. B 2008, 112, 16860-16873. [CrossRef]

81. Jones, D.P.; Carlson, J.L.; Mody, V.C.; Cai, J.; Lynn, M.J.; Sternberg, P. Redox state of glutathione in human plasma. Free Radic. Biol. Med. 2000, 28, 625-635. [CrossRef]

82. Meister, A.; Anderson, M.E. Glutathione. Ann. Rev. Biochem. 1983, 52, 711-760. [CrossRef] [PubMed]

83. Zelikin, A.N.; Becker, A.L.; Johnston, A.P.R.; Wark, K.L.; Turatti, F.; Caruso, F. A general approach for DNA encapsulation in degradable polymer microcapsules. ACS Nano 2007, 1, 63-69. [CrossRef] [PubMed]

84. Zhao, H.; Shen, K. G-quadruplex DNA-based asymmetric catalysis of michael addition: Effects of sonication, ligands, and co-solvents. Biotechnol. Prog. 2016, 32, 891-898. [CrossRef] [PubMed]

85. Lepecq, J.B.; Paoletti, C. A fluorescent complex between ethidium bromide and nucleic acids: Physical-Chemical characterization. J. Mol. Biol. 1967, 27, 87-106. [CrossRef]

86. Reichmann, M.E.; Rice, S.A.; Thomas, C.A.; Doty, P. A further examination of the molecular weight and size of desoxypentose nucleic acid. J. Am. Chem. Soc. 1954, 76, 3047-3053. [CrossRef]

(C) 2018 by the authors. Licensee MDPI, Basel, Switzerland. This article is an open access article distributed under the terms and conditions of the Creative Commons Attribution (CC BY) license (http://creativecommons.org/licenses/by/4.0/). 